Original Articles

\title{
Antiangiogenic compounds: well-established drugs versus emerging natural molecules
}

\author{
Andreia Ribeiro ${ }^{\text {a, b, c }}$, Rui M.V. Abreu ${ }^{\text {a, }}{ }^{* *}$, Madalena M. Dias ${ }^{\text {c }}$, Maria Filomena Barreiro ${ }^{b}$, \\ Isabel C.F.R. Ferreira ${ }^{\text {a, * }}$ \\ a Mountain Research Center (CIMO), ESA, Polytechnic Institute of Bragança, Bragança, Portugal \\ ${ }^{\mathrm{b}}$ Laboratory of Separation and Reaction Engineering - Laboratory of Catalysis and Materials (LSRE-LCM), Polytechnic Institute of Bragança, Bragança, \\ Portugal \\ ${ }^{c}$ Laboratory of Separation and Reaction Engineering - Laboratory of Catalysis and Materials (LSRE-LCM), Faculty of Engineering, University of Porto, Porto, \\ Portugal
}

\section{A R T I C L E I N F O}

\section{Article history:}

Received 14 August 2017

Received in revised form

17 November 2017

Accepted 1 December 2017

\section{Keywords:}

Angiogenesis

Molecular targets

Synthetic drugs

Natural compounds

\begin{abstract}
A B S T R A C T
Angiogenesis is the natural and physiologic process of growing blood vessels from pre-existing ones. Pathological angiogenesis occurs when the precise balance of all the molecular pathways that regulate angiogenesis is disrupted, and this process is a critical step in many diseases, including cancer. A limited number of antiangiogenic synthetic drugs have been developed. However, due to toxicity and side effects issues, the search for alternative to existing drugs is ongoing. In this sense, natural molecules obtained from plants or macrofungi, have demonstrated extraordinary potential in the treatment of angiogenesisrelated pathologies, specially taking into consideration its absence or very low toxicity, when compared to synthetic drugs. Using natural compounds as potential angiogenesis modulators is thus a promising field of research, supporting the creation of novel therapies able to reduce the use of drugs and associated side effects. In this review, the current status of antiangiogenic drugs and the wide variety of natural extracts and molecules with antiangiogenic capacities, as well as the angiogenesis molecular pathways and therapeutic targets, are presented. Finally, the challenges that need to be overcome in order to increase the use of natural compounds for clinical purposes are discussed.
\end{abstract}

(C) 2017 Elsevier B.V. All rights reserved.

\section{An overview of angiogenesis}

Angiogenesis is a biological process through which there is the formation of new blood vessels from pre-existing ones and occurs normally in the body under normal physiological conditions [1-3]. Angiogenesis naturally occurs during fetal development, tissue regeneration, wound healing and in the female reproductive cycle [1-4].

The trigger for normal angiogenesis is usually the detection of low levels of oxygen (hypoxia) by specific sensing mechanisms, in poorly perfused tissues, which stimulates the formation of new blood vessels to comply the cell metabolic requirements [5].

\footnotetext{
* Corresponding author.

** Corresponding author.

E-mail addresses: ruiabreu@ipb.pt (R.M.V. Abreu), iferreira@ipb.pt
} (I.C.F.R. Ferreira).
Alternatively, physiological angiogenesis is also triggered by mechanical tissue stretch [6].

Angiogenesis occurs in several steps, although some of these events may temporally overlap. The first step is the release of proteases that promote enzymatic degradation of the capillary basement membrane that triggers the migration of endothelial cells to the interstitial space and subsequent proliferation in cordlike form (sprout). The developing sprout elongates by proliferation of more endothelial cell and the two developing sprouts eventually fuse and form the lumen. Blood flow is then established and the newly formed blood capillary is stabilized through basement membrane deposition, pericyte recruitment and smooth muscle layer formation [7].

Although angiogenesis is a naturally occurring event, abnormal growth of new blood vessels is known to be involved in the development of various diseases including cancer, inflammation, eye illnesses, retinopathy, rheumatoid arthritis, among others $[2,8]$. Additionally, inadequate vessel preservation or growth may lead to ischemia causing myocardial infarction, stroke, and 


\begin{tabular}{ll} 
Abbreviations \\
AA-DLMs Arachidonic Acid-derived Lipid \\
Ang-1 & Angiopoietin \\
Akt & Protein Kinase B \\
ATP & Adenosine Triphosphate \\
BAEC & Bovine Aorta Endothelial Cells \\
CAM & Chick Chorioallantonic Membrane \\
Cdc37 & Cell Division Cycle Protein 37 \\
CDK4 & Cyclin Dependent Kinase 4 \\
CDK6 & Cyclin Dependent Kinase 6 \\
CDKs & Cyclin Dependent Kinases \\
CK2 & Casein Kinase II \\
c-KIT & Tyrosine-Protein Kinase Kit \\
c-Met & Tyrosine-Protein Kinase Met \\
COX-2 & Cyclooxygenase-2 \\
CRC & Colorectal Cancer \\
DNA & Deoxyribonucleic Acid \\
EGCG & Epigallocatechin-3-gallate \\
EGFR & Epidermal growth factor receptor \\
eNOS & Endothelial Nitric Oxide Synthase \\
ERK & Extracellular Signal - Regulated kinase \\
FDA & Food and Drug Administration \\
FGF & Fibroblast Growth Factors \\
GEJA & Gastro-Esophageal Junction Adenocarcinoma \\
GIST & Gastrointestinal Stromal Tumors \\
HCC & Hepatocellular Carcinoma \\
HIF-1 & Hypoxia-inducible Factor \\
HMEC & Human Microvascular Endothelial Cells \\
Hsp90 & Heat Shock Protein 90 \\
HUVECs & Human Umbilical Vein Endothelial Cells \\
IFN & Interferon \\
I $\kappa$ B & Inhibitor of kappa B \\
IKK- $\beta$ & Inhibitor of kappa B subunit $\beta$ \\
IL-1 & Interleukin - 1 \\
& \\
\hline
\end{tabular}

\section{Abbreviations}

AA-DLMsArachidonic Acid-derived Lipid

ATP Adenosine Triphosphate

BAEC Bovine Aorta Endothelial Cells

Chick Chorioallantonic Membrane

CDK4 Cyclin Dependent Kinase 4

CDK6 Cyclin Dependent Kinase 6

c-KIT Tyrosine-Protein Kinase Kit

CRC Colorectal Cancer

EGCG Epigallocatechin-3-gallate

EGFR Epidermal growth factor recepto

Endothelial Nitric Oxide Synthase

Food and Drug Administration

Fibroblast Growth Factors

GIST Gastrointestinal Stromal Tumors

Hepatocellular Carcinoma

HMEC Human Microvascular Endothelial Cells

Hsp90 Heat Shock Protein 90

IFN Interferon

IKK- $\beta \quad$ Inhibitor of kappa $B$ subunit $\beta$
IL-6

iNOS

LOX-5

MAPK Mitogen-Activated Protein Kinases

MMP Matrix Metalloproteinases

MOLT-4 Human Leukemia Cells

MTC Medullary Thyroid Cancer

NF- $\kappa$ B Nuclear Factor kappa B

nNOS Neuronal Nitric Oxide Synthase

NO Nitric Oxide

NOS Nitric Oxide Synthase

NSCL Non-Small-Cell Lung Carcinoma

PDGF Platelet Derived Growth Factor

PDGFR Platelet Derived Growth Factor Receptor

$\mathrm{PGA}_{2} \quad$ Prostaglandin A2

$\mathrm{PGD}_{2} \quad$ Prostaglandin D2

$\mathrm{PGE}_{2} \quad$ Prostaglandin E2

$\mathrm{PGF}_{2}-\alpha$ Prostaglandin F2- $\alpha$

$\mathrm{PGI}_{2} \quad$ Prostaglandin $\mathrm{I} 2$

PIK-3 Phosphoinositide 3-kinase

PKC Protein Kinase $\mathrm{C}$

PKC- $\alpha$ Protein Kinase $C \alpha$

RATEC Rate Adipose Tissue Endothelial Cells

RCC Renal Cell Carcinoma

RET $\quad$ Rearranged During Transfection

ROS Reactive Oxygen Species

RTK Receptor Tyrosine Kinase

STC Soft Tissue Carcinoma

Tie Angiopoietin receptor

TKI Tyrosine Kinase Inhibitors

TNF- $\alpha$ Tumor Necrosis Factor $-\alpha$

TSP-1 Thrombospondin-1

VEGF Vascular Endothelial Growth Factors

VEGFR-2 Vascular Endothelial Growth Factors Receptor - 2

YSM Yolk Chic Sac Membrane neurodegenerative diseases [1]. From a therapeutic point of view, in some diseases, including ischemic heart disease and peripheral arterial disease, the objective is to stimulate angiogenesis, while in other pathologies, including cancer, the goal is to inhibit abnormal angiogenesis.

The importance of angiogenesis in tumor development and metastases in cancer is well established. For tumor growth to occur, large amounts of nutrients and oxygen are necessary and, to overcome this situation, angiogenesis plays an important role in tumor development since it guarantees the survival of cells. Angiogenesis also facilitates the dissemination of tumor cells through the blood stream, achieving distant organs in the form of metastases $[9,10]$. Tumor angiogenesis occurs when tumor cells, as well as inflammatory cells aggregated to the tumor, produces angiogenesis factors that trigger the rapid development of angiogenesis [7,11]. Inhibition of tumor angiogenesis can thus decrease the blood flow, required for tumor development, and tumor cell growth would be ceased due to lack of nutrients and growth factors needed to support the formation of newly formed vessels [12].

Previous studies have identified and characterized numerous angiogenesis factors, both activators and inhibitors, which regulate angiogenesis. The most extensively studied angiogenesis regulators is vascular endothelial growth factor (VEGF) and the respective membrane receptors, mainly VEGFR-2, as they are recognized to play a major role in regulating physiological and pathological angiogenesis [13]. The first treatment that targeted tumor angiogenesis was monoclonal antibody bevacizumab, which acts by interacting and blocking VEGF interaction with its receptor. An alternative strategy to target VEGFR-2 is using small molecules like tyrosine kinase inhibitors (TKIs). This strategy resulted in the first clinically approved small molecule-like drugs that targeted tumoral angiogenesis: sunitinib and sorafenib $[14,15]$. VEGFR-2 inhibition is still being actively studied; it is considered an important strategy for angiogenesis inhibition [16] and towards the discovery of new anticancer drugs [17]. Many other angiogenesis therapeutic targets are currently being studied.

Natural compounds, present in medicinal and/or nutritional plants as well as in macrofungi sources, have stimulated a great interest from the pharmaceutical industry. Different natural compounds such as phenolic compounds, alkaloids, terpenoids among others, have shown strong antiangiogenic effects and can be considered as viable options to develop new strategies or drugs for targeting pathological angiogenesis. The low or even absent toxicity of these active compounds, make them an attractive alternative for human health maintenance. Chemoprevention is a promising anticancer approach with reduced secondary effects in comparison with synthetic drugs [18]. Chemoprevention consists in using other active molecules, such as naturally occurring anticancer agents, to inhibit or reverse some processes of carcinogenesis, including pathological angiogenesis [19]. The advent of diseases 
can thus be substantially prevented through new dietary habits, and the increased consumption of natural products have long been known to have a chemopreventive effect.

In the next section (Section 2) a survey of selected angiogenesis pathways and therapeutic targets will be presented, with emphasis on molecular mechanisms that have been targeted by natural molecules or natural sources. Section 3 will then review the current status of drugs used against angiogenesis, while Section 4 will provide an extensive review on the state of the art of known natural sources with antiangiogenic activity. Finally, Section 5 will focus on the challenges that natural products face to be used at a wider scale for medicinal purposes, thus as potential substitutes for the existing drugs.

\section{Angiogenesis molecular pathways and therapeutic targets}

The formation of new blood vessels is controlled by various angiogenic factors that act by triggering the signaling pathways leading to blood vessels formation and repairing. Other angiogenic factors may act by promoting the inhibition of angiogenesis, thus interfering with the formation of new blood vessels. The activation and inhibition effects of these angiogenetic factors are normally balanced so that blood vessels only form when needed by the organism. These angiogenic factors may be classified in different groups including growth factors, matrix metalloproteinases (MMP2 and MMP-9), cytokines, transcription factors, arachidonic acid derivatives and cell cycle related proteins, among others [1]. All of these angiogenic factors may be regarded as potential therapeutic targets, for treatment of conditions involving pathological angiogenesis. Some of the most widely studied angiogenic factors, as potential therapeutic targets, include vascular endothelial growth factor (VEGF), fibroblast growth factors (FGF), platelet derived growth factor (PDGF), matrix metalloproteinases, tumor necrosis factor alpha (TNF- $\alpha$ ) and hypoxia-inducible factor (HIF-1), just to name a few [20]. Therapeutic treatments that target angiogenic factors have in fact already been developed, with the notable example of antibodies and small TKIs against VEGF and respective receptors (Table 1). A brief description of some of the most studied angiogenic factors, and the respective molecular pathway, will be presented, highlighting the pathways that have already been targeted by natural compounds and sources. Fig. 1 presents an overview of the signaling pathways involved in angiogenesis, which were targeted by different natural molecules.

\subsection{Receptor tyrosine kinase (RTK)-mediated growth factors}

Growth factors like VEGF have received great attention, as well as their respective membrane receptor tyrosine kinase (RTKs): VEGFR-1, VEGFR-2 and VEGFR-3 [21]. Recent studies revealed that VEGF is the major mediator of endothelial cells angiogenesis signaling pathways, and is considered the main signal transducer in angiogenesis regulation $[3,12]$. VEGF acts by interacting with the extracellular domain of the respective RTKs, present in the membrane of endothelial cells. This interaction promotes VEGFR dimerization and activates the intracellular domain tyrosine kinase activity of VEGF receptors. The intracellular domain then phosphorylates and activates specific proteins involved in angiogenesis signaling pathways and this process eventually leads to stimulation of endothelial cell migration, proliferation and vascular formation [6]. For the development of new angiogenic inhibitors, the inhibition of VEGFR-2 has attracted great attention, since several monoclonal antibodies and TKIs have shown that it was possible to stop tumor angiogenesis, by blocking interaction between VEGF and his receptor VEGFR-2, present in the membrane of endothelial cells [12].

Another growth factor involved in angiogenesis is the plateletderived growth factor (PDGF) that acts by activating specific RTKs proteins (PDGFR $\alpha$ and PDGFR $\beta$ ), present in the membrane of endothelial cells. PDGF stimulates pericyte recruitment, a process that is fundamental on blood vessel maturation [22], resulting in the stabilization of the capillary wall [23]. Moreover, has been shown that PDGF and VEGF work symbiotically in order to stimulate formation and stabilization of the new blood vessels [22].

Table 1

Drugs currently in clinical use that affect angiogenesis.

\begin{tabular}{|c|c|c|c|c|}
\hline Drug & Mode of action & Approved indications & Year of approval & References \\
\hline $\begin{array}{l}\text { Bevacizumab } \\
\text { (Avastin) }\end{array}$ & VEGF Antibody & CRC, NSCLC, RCC, breast cancer & 2004 & [4] \\
\hline $\begin{array}{l}\text { Cabozantinib } \\
\text { (Cabometyx) }\end{array}$ & $\begin{array}{l}\text { RTK Inhibitor } \\
\text { (VEGFR, c-Met) }\end{array}$ & MTC; RCC & 2011 & [174] \\
\hline $\begin{array}{l}\text { Lenalidomide } \\
\text { (Revlimid) }\end{array}$ & VEGF expression inhibitor & Multiple Myeloma & 2004 & [114] \\
\hline $\begin{array}{l}\text { Pazopanib } \\
\text { (Votrient) }\end{array}$ & $\begin{array}{l}\text { RTK Inhibitor } \\
\text { (c-KIT, FGFR, PDGFR and VEGFR) }\end{array}$ & RCC, STS & 2009 & [175] \\
\hline $\begin{array}{l}\text { Ramucirumab } \\
\text { (Cyramza) }\end{array}$ & VEGFR Antibody & GEJA, NSCL & 2014 & {$[176]$} \\
\hline $\begin{array}{l}\text { Regorafenib } \\
\text { (Stivarga) }\end{array}$ & $\begin{array}{l}\text { RTK Inhibitor } \\
\text { (VEGFR, Tie) }\end{array}$ & CRC, GIST & 2012 & [177] \\
\hline $\begin{array}{l}\text { Sorafenib } \\
\text { (Nexavar) }\end{array}$ & $\begin{array}{l}\text { RTK Inhibitor } \\
\text { Multi-RTK inhibitor }\end{array}$ & RCC, HCC; MTC & 2005 & [14] \\
\hline $\begin{array}{l}\text { Sunitinib } \\
\text { (Sutent) }\end{array}$ & $\begin{array}{l}\text { RTK Inhibitor } \\
\text { (Kit,VEGFR-2 and PDGFR inhibitor) }\end{array}$ & GIST, RCC & 2006 & [15] \\
\hline $\begin{array}{l}\text { Thalidomide } \\
\text { (Immunoprin) }\end{array}$ & $\begin{array}{l}\text { TNF- } \alpha \text { and IL- } 6 \text { expression inhibitor, } \\
\text { NF- } \kappa \text { B and COX- } 2 \text { inhibitor }\end{array}$ & Multiple Myeloma & 2006 & [178] \\
\hline $\begin{array}{l}\text { Vandetanib } \\
\text { (Caprelsa) }\end{array}$ & $\begin{array}{l}\text { RTK Inhibitor } \\
\text { (VEGFR-2, EGFR and RET) }\end{array}$ & MTC & 2011 & [179] \\
\hline
\end{tabular}

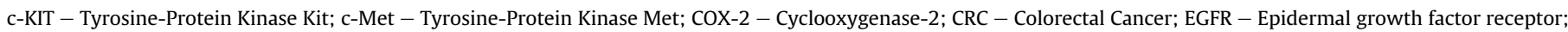

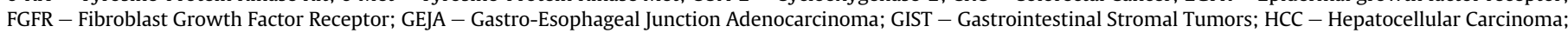

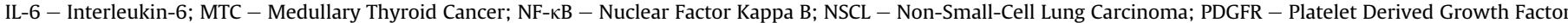

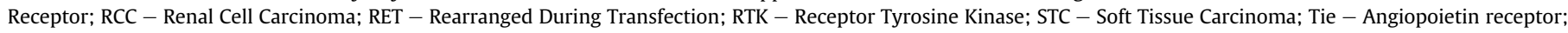
TNF- $\alpha$ - Tumor Necrosis Factor - $\alpha$; VEGF - Vascular endothelial Growth Factor; VEGFR - Vascular Endothelial Growth Factor Receptor. 


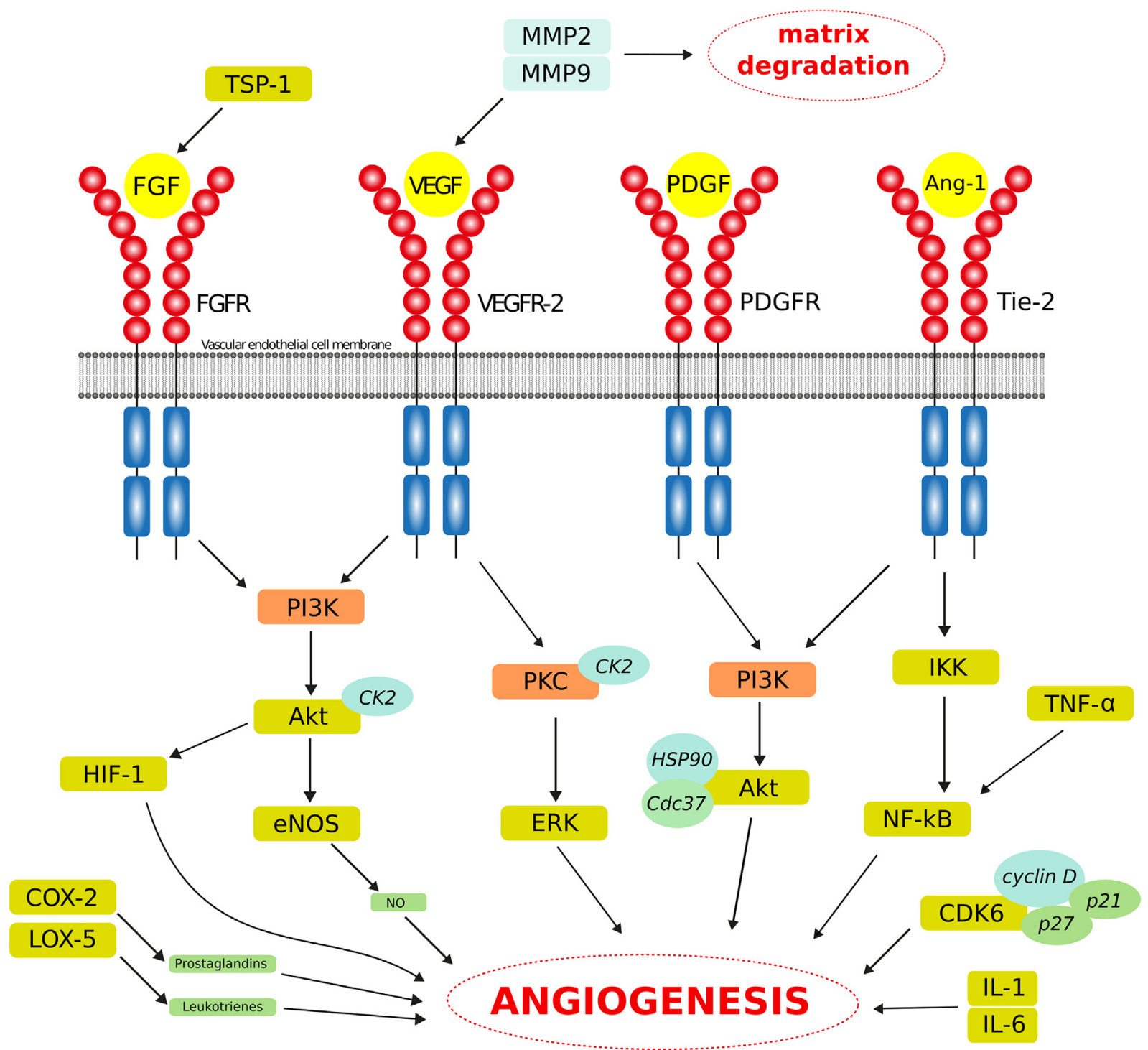

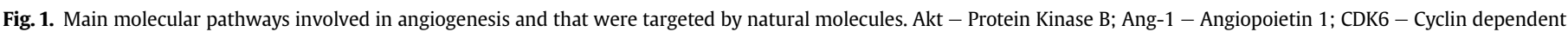

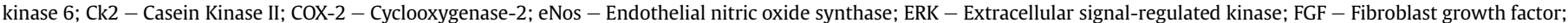

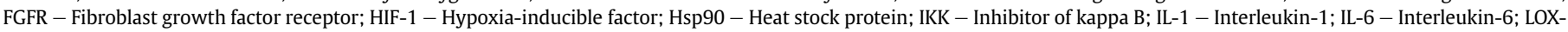

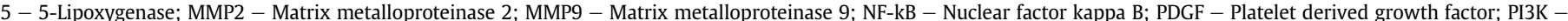

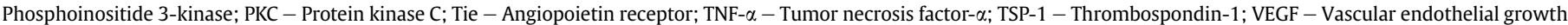
factor; VEGFR-2 - Vascular endothelial growth factor receptor 2.

Another RTK-mediated growth factor involved in angiogenesis is the fibroblast growth factor (FGF), known to be expressed by tumor cells [1]. FGF can be directly related with tumor cells proliferation, specifically the FGF-2 isoform, known to induce endothelial cell proliferation and migration by interacting with specific RTKs present in the membrane of endothelial cells [11,24]. Overall, FGF plays an important role in angiogenesis and evidence suggest the existence of cross talk and synergism between FGF and other growth factor pathways [25].

Finally, angiopoietin receptor-2 (Tie-2) is a transmembrane tyrosine kinase receptor, which binds to angiopoietins being also involved in regulating angiogenesis, among other cell activities. Angiopoietins are growth factors required for the formation of blood vessels, and Angiopoietin-1 (Ang-1) in known to downregulate nuclear factor kappa $\mathrm{B}$ (NF-kB) complex, by binding to Tie2 membrane receptor, via disruption of the IKK complex [26].

\subsection{Matrix metalloproteinases}

Matrix metalloproteinases (MMP) are proteinases participating in extracellular matrix degradation, a normal physiological process that is crucial in several biological events such as embryogenesis, cell proliferation, apoptosis, but also in angiogenesis [25]. Several MPPs were shown to be involved in pathological processes, for example in cancer development and metastasis, by promoting dysregulation of the basement membrane composition, thus facilitating apoptosis [27-30]. Specifically, MMP-2 and MMP-9 (also known as Gelatinase A and B, respectively) digest denatured collagens and were related to the cancer invasion process, as tumor cells must cross the collagen-rich basement membrane of blood vessel walls, in order to grow to distant locals from the primary tumor $[27,28]$. As an example of this process, the MMP-9 presents an important role in the pathological angiogenesis in malignant glioma [31] and diabetic retinopathy [30]. 


\subsection{Cytokines}

Cytokines are a diverse group of low molecular weight proteins that are involved in a number of cell signaling pathways that regulate as diverse cellular events as the immune response, inflammation and cancer, among others. It has been long recognized that the immune response is tightly associated with the endothelial process of angiogenesis, and that this association is implemented by way of cytokines that are produced during the immune response [32]. Endothelial cells have also been recognized for having the ability to generate abundantly cytokines [33]. These substances influence the intensity of the angiogenic response induced essentially during inflammation. The angiogenic effects attributed to cytokines has also been related with the ability to prime endothelial cells for the subsequent action of VEGF [34].

The protein cytokine interleukin-6 (IL-6) is involved in several biological activities, including hematopoiesis, immune responses and inflammation. This protein is secreted mainly by immune cells $[35,36]$ and is hardly detectable under normal physiological conditions [36], although its induced biological responses are important in controlling inflammation and in maintenance of tissue homeostasis [35]. However, levels of IL-6 are significantly changed in pathological conditions; in particular, in inflammatory bowel disease, autoimmune acute phenomena, myeloma and arthritis [36], and part of IL-6 influence is by inducing leukocytosis and angiogenesis [37].

Other cytokine that also plays an important action in inflammatory diseases is interleukin-1 (IL-1), being a potent mediator in response to injury and infections [38]. IL-1 is mainly produced by myeloid cells and initiates and propagates inflammation mainly by inducing a local network of cytokines [30]. Pro-inflammatory mediators, including IL-1, have recently been shown to play an important role in tumor-mediated angiogenesis, and IL-1 inhibition is now considered as a potential target for anti-cancer therapy [39].

Tumor necrosis factor $\alpha$ (TNF- $\alpha$ ) is an inflammatory cytokine, normally found in high concentrations in tissues subject to inflammation processes, being primarily produced by activated macrophages, T lymphocytes and natural killer cells [40]. Some studies reported that TNF- $\alpha$ is commonly found along the joints, leading to production of several pro-inflammatory effects, thus contributing to joint degradation $[41,42]$. Furthermore, TNF- $\alpha$ plays an important role the NF- $\mathrm{BB}$ signaling pathway initiation [43].

In general, in normal plasma concentrations, IL-1, IL-6 and TNF$\alpha$ act together in promoting pathogens elimination, through increasing the body temperature (fever) and leukocytosis [36]. However, when found in high concentrations, they constitute activators of severe and acute inflammatory and immune responses, which have been associated with angiogenesis activation [39]. These cytokines have thus been recognized as potential targets for therapeutic antiangiogenic interventions $[36,44]$.

\subsection{Transcription factors}

Transcription factors are proteins that are involved in gene expression regulation, by binding to specific deoxyribonucleic acid (DNA) sequences. Hypoxia-induced factor (HIF-1) is a transcription factor that plays an important role in the organism response to low oxygen concentrations scenarios (hypoxia), by regulating the expression of genes that facilitate adaptation and survival of cells in hypoxia situations $[45,46]$. In developing embryos, angiogenesis is a key process that is largely controlled by HIF-1 mediated hypoxia. The release of HIF-1 stimulates the expression of angiogenic factors, including VEGF. However, HIF-1 is also the main factor responsible for increasing the vascularization of hypoxic areas, which occur in ischemia situations and in tumor growth [46]. Although HIF-1 is essential for the regulation of angiogenesis, it also promotes survival and proliferation of cancer cells, due to its angiogenic properties [47].

Nuclear factor kappa B (NF-kB) is a protein complex that acts as a transcription factor that is involved in several physiological processes including immune and inflammatory responses [48]. The NF-kB family is constituted by p65, RelB, c-Rel, p50 and p52 subunits, which act as homo or hetero-dimers [49]. Typically, the NF$\mathrm{kB}$ complex remains inactive in the cytosol, by forming a protein complex with IkB (inhibitor of kappa B). By external stimulation, IkB is phosphorylated and targeted for degradation, thus freeing and enabling NF-kB gene expression activity [49,50]. However, dysregulation of NF-kB activity, plays a critical role in angiogenic, inflammatory and autoimmune diseases as well as in the cancer process [30]. NF-kB is involved in oncogenesis and tumor cell resistance, due to inadequate gene expression of several factors involved in apoptosis suppression, cell adhesion and proliferation [49]. The kinase responsible for the phosphorylation of IkB is IKB kinase- $\beta$ (IKK- $\beta$ ), which is part of the IKK complex [51]. IKK- $\beta$ is thus considered an angiogenesis inducer and is also regarded as a potential antiangiogenic target [51,52].

\subsection{Cyclooxygenase 2 (COX-2) and 5-lipoxygenase (LOX-5)}

Arachidonic acid-derived lipid mediators (AA-DLMs) are involved in the inflammation process and are biosynthesized by pathways dependent on cyclooxygenase (COX) and lipoxygenase (LOX) enzymes. COX-2 is a key enzyme in the biosynthesis of prostaglandins, a family of AA-DLMs that include Prostaglandin E2 $\left(\mathrm{PGE}_{2}\right)$, Prostaglandin D2 $\left(\mathrm{PGD}_{2}\right)$, Prostaglandin F2 $\alpha(\mathrm{PGF} 2 \alpha)$, Prostaglandin I2 $\left(\mathrm{PGI}_{2}\right)$ and prostaglandin A2 $\left(\mathrm{PGA}_{2}\right),[53,54]$. Additionally, 5-lipoxygenase (LOX-5) participates in the conversion of arachidonic acid to leukotrienes, the second largest family of AADLMs [55]. COX2 and LOX-5 mediated biosynthesis of AA-DLMs, plays an important role in the inflammation process, which occur in different conditions including rheumatoid arthritis, neuroinflammation and psoriasis [53-55]. Due to the contribution of COX-2 and LOX-5 in the inflammatory process, there is a large interest in the use of new drugs as inhibitors of these oxygenase enzymes [56,57]. Recently, the upregulation of COX-2 was reported in situations where antiangiogenic therapies were applied, specifically in treatment with anti-VEGFR-2 antibodies and sunitinib. When COX-2 is inhibited, the production of PGE2 levels diminish and the anti-VEGFR2 therapy efficiency improves. Following COX-2 inhibition, a reduction of tumors infiltration by cancer-associated fibroblasts is observed. Clinical investigations are ongoing to investigate the cooperative inhibition of COX-2 and VEGF-signaling capable to block tumor angiogenesis [58].

\subsection{Cell cycle related proteins}

The complexity of angiogenesis provides many targets for therapeutic intervention and a number of proteins, which are involved in the cell cycle complex machinery, have been studied as angiogenic modulators. Cyclin dependent kinases (CDKs) are serine/threonine kinases, which belong to the core cell cycle machinery, and exert their kinase activity when bounded to cyclins [59]. Cyclin D1 is an important cycle progression regulation and can also function as a co-transcriptional regulator by forming a complex with CDK6 kinase [60]. Overexpression of cyclin D1 has been shown to lead to accelerated G1 progression and chromosome instability in several cell types [61], and some studies relate the amount of cyclin D1 with cancer manifestation [62]. CDK6-cyclin D1 complex was also shown to be involved in tumor angiogenesis, through regulation of VEGF synthesis [62]. Also, cell cycle inhibitor proteins, 
namely p21 and p27, were shown to block cell cycle progression by binding and inhibiting CDK-cyclin complexes [63], thus promoting cell cycle arrest, growth arrest and differentiation or senescence, in response to various stimuli [64]. Besides its ability to inhibit the activity of cyclin-dependent kinase, p21 also operates as a mediator of p53 tumor suppressor activity. Also, expression of p53 in cells can induce cell growth arrest through transcriptional activation of p21 [65]. Both p21 and p53 up-regulation can thus be viewed as potential therapeutic routes for tumor angiogenesis inhibition [66].

Heat shock protein 90 (Hsp90) is an essential adenosine triphosphate (ATP) dependent molecular chaperone, and is abundantly expressed in eukaryotic cells $[67,68]$. Hsp90 plays an important role in various cellular processes, among which cell cycle control, cell survival and different signaling pathways can be cited [69]. Hsp90 overexpression has been related to tumor cells survival, in adverse conditions such as lack of nutrients, hypoxia and acidosis [68]. Hsp90 has also been related to tumor angiogenesis, and recent studies have suggested that Hsp90 inhibitors promote angiogenesis inhibition, by affecting the PI3K/Akt/eNOS (phosphoinositide 3kinase/protein kinase $\mathrm{B} /$ endothelial nitric oxide) signal transduction pathway in endothelial cells, as well as through downregulation of VEGFR-2 expression [70].

Akt (also known as protein kinase B) is another serine/theronine kinase that has been recognized to be involved in the signaling pathways leading to cell proliferation, cell growth and survival [71], and the dysregulation of this kinase is related with various human diseases including diabetes, cancer and cardiovascular diseases [72]. Akt is activated by interacting with Hsp90, thus it is also recognized as a potential target in abnormal angiogenesis [71]. Cell division cycle 37 (Cdc37) protein has shown significant influence in cell proliferation, mainly in cancer cells [73]. Cdc37 promotes its function by forming complexes with oncogenic protein, including Hsp90, Raf1 and cyclin dependent kinase 4 (CDK4) [73]. Thereby, several authors have indicated Cdc37 as being involved in Hsp90 activation and subsequent tumor angiogenesis induction through Akt activation [74,75].

Extracellular signal-regulated kinase (ERK) is another serine/ threonine kinase, which is a member of the mitogen-activated protein kinases (MAPK) kinase family that is known to be involved in various cellular functions, and in different cell types [76]. ERK is activated by different growth factors and cytokines, and have been reported to play pivotal roles in many aspects of cell function such as proliferation, differentiation and survival [77]. Phosphorylation of the ERK is induced by VEGF and, in this phosphorylated form, ERK is known to induce angiogenesis in endothelial cells. Inhibition of ERK was shown to prevent endothelial sprouting, although not initial artery differentiation. These studies implicate ERK as a specific effector of VEGFR signaling pathway, in the induction of angiogenic genes during sprouting [78].

\subsection{Other intracellular angiogenic modulators}

The most antique antiangiogenic factor to be identified was thrombospondin-1 (TSP-1). TSP-1 is an endogenous inhibitor and its antiangiogenic ability was related to the capability of interacting with FGF-2, thus preventing interaction between FGF-2 and the soluble heparin or endothelial cells heparin sulfate proteoglycans [79], thereby avoiding the progression of the angiogenic process. Angiostatin and endostatin were subsequently identified and both participate in antiangiogenic processes. Angiostatin is polypeptide that occur naturally in various animal species, including humans. It is classified as endogenous angiogenesis inhibitor and your capacity is related with downregulating VEGF expression blocking one the major vascular growth factors [80,81]. Like angiostatin, endostatin is also a polypeptide. Endostatin is derived from collagen XVIII (created by digestion of the $\mathrm{C}$ terminal fragment of collagen) [82,83], it participates in inhibition of endothelial cells proliferation inhibiting many steps of angiogenesis [82,84]. The inhibition of VEGF, metalloproteinases and cyclin D1 is the most important ways that endostatin act for block the angiogenesis process [85]. Both proteins, angiostatin and endostatin, are expressed in pathological situations, such as pathological angiogenesis, and plays a critical role in inhibition of primary metastatic tumor growth [83].

The interferons are another molecules that act as angiogenesis inhibitor and can be classified in two classes: interferon-alpha (IFN$\alpha)$ and interferon-beta (IFN- $\beta$ ) and both are cytokines. These interferons were one of the first to be used in association with chemotherapeutic agents in clinical trials of human tumors [86]. Thus, the IFN- $\alpha$ has been recognized as powerful angiogenic inhibitor [87] and though that IFN- $\alpha$ potential in angiogenic processes is mainly attributed to inhibition of FGF, decrease VEGF gene expression and downregulation of interleukin-8 production $[87,88]$. Additionally, the IFN- $\alpha$ has also direct effects on EC avoiding of their proliferation and migration [87]. Relatively to the IFN- $\beta$ is described with capacities to decrease MMP-2 production through suppressing gene expression and down relate FGF expression [86].

Integrins belongs to heterodimeric transmembrane receptors (composed by an $\alpha$ - and a $\beta$-subunit) mediated cell-extracellular matrix adhesion [89] and coordinate a large amount of cellular activities in response to the extracellular environment [89]. Integrins receptors are important in angiogenic development [90] and, actuality, integrins represent an important target for pharmaceutical agents in order to create innovative ways for angiogenesis and metastatic control [91].

Neovastat is a product derived from shark cartilage (Æ-941) [92] and the main functionality is related with inhibition of two main mechanism of angiogenesis activation, in specific, VEGF (competes with VEGF for binding to VEGFR and inhibit the receptor activation) and MMP [92,93]. Additionally, the neovastat also shows a significant anti-tumor and anti-metastatic properties [93] and more recently the neovastat was also described with anti-inflammatory properties [94]. Furthermore, neovastat not revealed adverse side effects when applied in clinical uses.

Nitric oxide (NO) belongs to reactive oxygen species (ROS) and is catalyzed by the nitric oxide synthase (NOS) enzyme family [95,96]. Three NOS isoforms were identified including neuronal (nNOS), endothelial (eNOS) and inducible (iNOS) [96,97] and all isoforms play important biological functions. However, accumulated evidence suggests that NO production by eNOS, may play an important role in ischemic disorders by promoting neovascularization, and in tumor angiogenesis through Akt/eNOS signaling pathway activation. eNOS is thus regarded as a potential therapeutic target, either through activation in ischemic angiogenesis or through inactivation in tumor angiogenesis [70,98].

Casein Kinase II (CK2) is a serine/threonine kinase, which catalyzes the phosphorylation of several cytoplasmic and nuclear proteins [99]. CK2 participates in the regulation of multiple biological process including, survival, proliferation and cellular differentiation [100]. There is an increasing evidence pointing out that CK2 also plays an essential role in angiogenesis, either by interaction or phosphorylation of growth factors or proteins involved in angiogenesis signaling cascades [101]. Moreover, in tumor cells, the expression and activity of CK2 is frequently high to ensure cell growth [102]. CK2 inhibitors used for cancer treatment have found to be also angiogenesis inhibitors, and CK2 is widely regarded as a therapeutic target for cancer treatment and tumor angiogenesis [101].

Protein kinase $\mathrm{C}(\mathrm{PKC})$ is another serine/threonine kinase that acts as an intracellular messenger, with important roles in 
proliferation and migration of endothelial cells [79]. PKC is also known to be involved in RTKs-mediated angiogenesis signaling pathways, and its inhibition was shown to promote angiogenesis. The inhibition of PKC is thus regarded as a novel strategy for therapeutic angiogenesis, in cases of ischemic cardiovascular diseases [103].

\section{Antiangiogenic drugs}

The development of drugs that act as angiogenic inhibitors has become essential for the treatment of various types of cancer (Table 1). The main objective of these antiangiogenic drugs is to deprive tumor cells of oxygen and nutrients, thus preventing the formation of new blood vessels and therefore limiting tumor growth [104]. An extensive, yet non-exhaustive, account of angiogenesis molecular pathways and targets was presented in chapter 2 (Fig. 1). Still, the majority of drugs in clinical use where developed, either as RTK inhibitors or as growth factor inhibitors, that activates the respective RTK (Fig. 2) [104,105]. The explanation for this lack of therapeutic targets diversity is probably due to the fact that antiangiogenic drugs in clinical use are relatively recent. In fact, it was only in 2004 that bevacizumab (Avastin) was approved as the first antiangiogenic drug cancer treatment, by the USA Food and Drug Administration (FDA) [106,107]. Bevacizumab is a monoclonal antibody that specifically binds to VEGF, thus preventing it to interact and activate their RTK receptors [108]. Initially it was approved as a first-line treatment in metastatic colorectal cancer (CRC) and subsequently for treatment in cervical, non-small cell lung (NSCL), renal cell and glioblastoma cancers [106,109,110]. With the increased interest in antiangiogenic drugs, other compounds were developed over the years (Table 1). These compounds can be essentially divided in three families: antibodies targeting VEGF or his membrane RTKs (Bevacizumab and Ramucirumab); small molecule inhibitors of RTKs (Cabozatinib, Pazopanib, Regorafenib, Sorafenib, Sunitinib and Vandetanib) and small molecule inhibitors targeting proteins involved in angiogenesis signaling pathways, downstream membrane RTKs activation, either directly or by<smiles>CNC(=O)c1cc(Oc2ccc(NC(=O)Nc3ccc(Cl)c(C(F)(F)F)c3)cc2)ccn1</smiles><smiles>Cc1ccc(Nc2nccc(N(C)c3ccc4c(C)n(C)nc4c3)n2)cc1S(N)(=O)=O</smiles>

Pazopanib<smiles>CCN(CC)CC/N=C(\O)c1c(C)[nH]c(/C=C2\C(O)=Nc3ccc(F)cc32)c1C</smiles>

Sunitinib<smiles>Nc1cccc2c1CN(C1CCC(=O)NC1=O)C2=O</smiles>

Lenalidomide<smiles>CCCCCCCCC(C)(C)Oc1cc2c(Oc3ccc(NC(=O)C4(C(=O)Nc5ccc(F)cc5)CC4)cc3)ccnc2cc1OC</smiles><smiles>CNC(=O)c1cc(Oc2ccc(NC(=O)Nc3ccc(Cl)c(C(F)(F)F)c3)c(F)c2)ccn1</smiles>

Regorafenib<smiles>COc1cc2c(Nc3ccc(Br)cc3F)ncnc2cc1OCC1CCN(C)CC1</smiles>

Vandetanib<smiles>O=C1CCC(N2C(=O)c3ccccc3C2=O)C(=O)N1</smiles>

Thalidomide

Fig. 2. Antiangiogenic drugs in clinical use. 
inhibiting its expression (Lenalidomide and Thalidomide) [104,106].

Sorafenib was the first small RTK inhibitor drug to be developed and was initially approved against renal cell carcinoma, then against hepatocellular carcinoma (HCC) and more recently for differentiated thyroid treatment [111]. Sunitinib soon followed, being approved for gastrointestinal stromal tumors, rare stomach cancers and renal cell carcinoma [106,112]. Other RTK inhibitors approved for antiangiogenic clinical use includes: pazopanib, approved against advanced renal cell carcinoma and soft tissue sarcoma; vandetanib, approved against advanced medullary thyroid cancer situations that cannot be removed by surgery; carbozoantinib also approved against medullary thyroid cancer and renal cell carcinoma and vandetanib, approved against medullary thyroid cancer [107].

Thalidomide is a drug used for several decades for the treatment of various diseases, but was only approved as an anticancer drug in 2006, being approved against multiple myeloma. The precise mechanism of its antiangiogenic activity was not yet fully elucidated, although several activities that probably account for its activity, including TNF- $\alpha$, IL-6 expression inhibition and NF- $\kappa \mathrm{B}$ and COX-2 direct inhibition, were observed [113]. Lenalodomide belongs to the same type of inhibitors as thalidomine, being also used against multiple myeloma by inhibiting VEGF expression (Table 1) [114].

Despite the various molecules involved in the angiogenic process, most of these drugs have greater affinity for acting on tyrosine kinases, particularly the VEGF and respective receptor [104,105]. For example, bevacizumab is a monoclonal antibody that specifically recognize and binds to VEGF, making this growth factor unable to activate the receptor [108]. Other inhibitors bind to receptors, at the surface of endothelial cells, or to other proteins in the downstream signaling pathways that block their activities [112].

A common problem when using antiangiogenic drugs is the common situation of drug resistance. Although initially there is a positive response to the drugs, and the tumor angiogenesis is blocked, eventually the tumor acquires resistance and circumvents the pathway that is blocked, normally the VEGF/VEGFR2 target pair. Resistance is usually acquired when the tumor is able to growth, by enabling VEGF/VEGFR-2 independent pathways, thus promoting tumor angiogenesis [112]. An alternative to overcome the antiangiogenic drugs resistance is by their combination with other conventional therapies, including chemotherapy or radiation [19]. Combined therapies may have a synergistic effect when compared to the single drug therapies [115]. For example, bevacizumab sometimes is used with other drugs such as 5-fluorouracil or chemotherapy, to enhance treatment against various types of cancers [116].

Another factor to highlight is the toxicity that antiangiogenic drugs have in the body, contributing to side effects and leading sometimes to serious injuries [112]. The more common effects experienced by patients are hypertension, diarrhea, decrease of white blood cells, fatigue, taste modification and appetite reduction, weight loss, nausea, abdominal pain, skin reactions and hypocalcemia $[110,112,117]$, and more frequent complications include hepatic toxicity, arterial and venous thrombotic events, gastric cancer and stroke $[110,112]$. Still, each drug is administered to different types of cancer and at distinct doses among patients, they result in more or fewer side effects in the body. In this sense, it becomes essential to develop new drugs with lower or no toxicity, and with the ability to prevent pathological angiogenesis [19]. Researchers have thus focused in antiangiogenic molecules that occur naturally in plants. These compounds are accessible, have low or minimal toxicity, and have been traditionally used for many years in the treatment of various diseases [47].

\section{Natural sources of antiangiogenic compounds}

Since primitive societies, plants, herbs and seeds, rich in phytochemicals, were used due to their benefits in human health. These molecules were shown to present a diverse array of action mechanisms, including antioxidant activity, enzyme stimulation, hormones mimicking and by interfering with DNA replication [115]. Phytochemicals have thus demonstrated positive effects in health, especially in cancer prevention [118]. Thereby, secondary plant metabolites have been considered as potential candidates for inhibition of pathological angiogenesis $[47,119,120]$. In some situations, in order to increase the benefits/properties of plants, extractions are conducted. Extractions allow the isolation of active ingredients, which may subsequently be administered at higher dosage, in order to obtain higher therapeutic effects [47]. Also, extracts may contain various phenolic compounds in natural proportions that, through synergistic interactions between them, complement each other's biological activity [19].

\subsection{Antiangiogenic potential of extracts from plant and macrofungi origin}

The information regarding the antiangiogenic potential of bioactive extracts, obtained from different natural sources, is summarized in Table 2, as well as the test/cell/model used, and their mechanism of action. Of note, is that methanolic and ethanolic extractions were the predominantly use methods with natural sources. The extracts have diverse mechanisms of action, and the same extract may have different pathways to inhibit angiogenesis. Different bioactive compounds may present distinct activities at different molecular levels [19].

In the work developed by Zhu et al. [121], artemisinin was isolated from an ethanolic extraction of Arteminisia annua L. and evaluated for its angiogenesis inhibition potential. Artemisinin contributed to a significant reduction of $\mathrm{PGE}_{2}$ production in rat peritoneal cells and human peripheral blood mononuclear cells. Ghalib et al. [122] studied the antiangiogenic activity in HUVEC's of aspfalcolide, a compound isolated from a chloroform extract obtained from Asparagus falcatus L. leaves. The results showed a remarkable inhibitory effect of aspfalcolide on the proliferation ( IC $_{50} 1.82 \mu \mathrm{M}$ ), migration and tube formation of human umbilical vein endothelial cells (HUVECs). Guimarães et al. [123] evaluated the potential of Chamaemelum nobile L. methanolic and aqueous extracts as angiogenesis inhibitors, through VEGFR-2 inhibition. The methanolic extract showed superior VEGFR-2 inhibition, when compared with the aqueous. Huang et al. [124] observed that a supercritical fluid extract of Croton crassifolius had potent antiangiogenic activity on the zebrafish model. They verified that cyperenoic acid is the active component present in the extract, and that this compound interferes with multiple molecular targets related to angiogenesis, including the growth factors VEGF and angiopoitein (Ang), and their respective RTKs (VEGFR and Tie-2). The antiangiogenic potential of Eurycoma longifolia methanol extract was studied by Al-Salahi et al. [125], using CAM (Chick chorioallantonic membrane), rat aortic, and HUVEC's assay models. They observed several angiogenesis inhibition related phenomena, including inhibition of neovascularization, suppression in sprouting of microvessels and inhibition of proliferation, migration and differentiation of HUVEC cells. Ahn et al. [95] investigated the antiangiogenic potential of ethanol extract and subsequent $\mathrm{BuOH}$ fraction of Gastrodia elata Blume, in CAM assay and murine 
Table 2

Antiangiogenic extracts from plant and macrofungi origin.

\begin{tabular}{|c|c|c|c|c|c|}
\hline Species & Extract type & Bioactive compounds & Assay/Cells/Model & $\begin{array}{l}\text { Mechanisms/effects of } \\
\text { antiangiogenic action }\end{array}$ & References \\
\hline \multicolumn{6}{|l|}{ Plants } \\
\hline Artemisia annua $\mathrm{L}$. & Ethanol extract & $\begin{array}{l}\text { Artemisinin } \\
\text { (sesquiterpene lactone) }\end{array}$ & $\begin{array}{l}\text { Rat peritoneal cells; } \\
\text { PBMC }\end{array}$ & Inhibition of PGE2 production & {$[121]$} \\
\hline Asparagus falcatus Linn & Chloroform extract & $\begin{array}{l}\text { Aspfalcolide } \\
\text { (sesquiterpene lactone) }\end{array}$ & HUVECs & $\begin{array}{l}\text { Inhibition of VEGF-induced HUVECs } \\
\text { proliferation, migration and tube } \\
\text { formation }\end{array}$ & [122] \\
\hline Chamaemelum nobile L. & $\begin{array}{l}\text { Methanol extract and } \\
\text { aqueous extract }\end{array}$ & - & $\begin{array}{l}Z^{\prime}-\text { Lyte }^{\mathrm{TM}} \text { Kinase assay } \\
\text { Kit }\end{array}$ & Inhibition of VEGFR-2 activity & [123] \\
\hline Croton crassifolius Geiseler & $\begin{array}{l}\text { Supercritical fluid extract } \\
\left(\mathrm{CO}_{2}\right)\end{array}$ & $\begin{array}{l}\text { Cyperenoic acid } \\
\text { (terpenes) }\end{array}$ & Zebrafish & $\begin{array}{l}\text { Effects on VEGF-A, Ang and } \\
\text { respective receptors }\end{array}$ & [124] \\
\hline Eurycoma longifolia Jack & Methanol extract & - & $\begin{array}{l}\text { CAM } \\
\text { Rat aortic } \\
\text { HUVECs }\end{array}$ & $\begin{array}{l}\text { Inhibition of neovascularization } \\
\text { Suppression in sprouting of } \\
\text { microvessels } \\
\text { Inhibition of proliferation, } \\
\text { migration and } \\
\text { differentiation }\end{array}$ & [125] \\
\hline Gastrodia elata Blume & $\begin{array}{l}\text { Ethanol extract } \\
\text { Fraction: n-butanol }\end{array}$ & - & $\begin{array}{l}\text { Murine macrophage } \\
\text { cell line CAM }\end{array}$ & $\begin{array}{l}\text { Inhibition of NO production and } \\
\text { COX-2 } \\
\text { Inhibition of vascular permeability }\end{array}$ & [95] \\
\hline Origanum onites L. & Essential oil & - & $\begin{array}{l}\text { 5RP7 } \\
\text { RATEC }\end{array}$ & $\begin{array}{l}\text { Inhibition of cell viability and } \\
\text { induction of apoptosis; } \\
\text { May block tube formation and } \\
\text { migration }\end{array}$ & [126] \\
\hline Pinus halepensis Mill. & $\begin{array}{l}\text { Lipid fraction } \\
\text { (chloroform/methanol, 2:1) }\end{array}$ & $\begin{array}{l}\text { Neutral lipids, glycolipids, } \\
\text { and phospholipids }\end{array}$ & $\begin{array}{l}\text { EC } \\
\text { CAM }\end{array}$ & $\begin{array}{l}\text { Inhibition of cells tubes formation } \\
\text { Inhibition of blood vessels growth }\end{array}$ & [127] \\
\hline \multicolumn{6}{|l|}{ Mushrooms } \\
\hline $\begin{array}{l}\text { Ganoderma lucidum (Curtis) } \\
\text { P. Karst. }\end{array}$ & Methanol extract & $\begin{array}{l}\text { Ganoderic acid F } \\
\text { (lanostane triterpenoid) }\end{array}$ & HUVECS & $\begin{array}{l}\text { Inhibition of capillary-like } \\
\text { structures formation }\end{array}$ & [128] \\
\hline $\begin{array}{l}\text { Phellinus linteus (Berkeley \& } \\
\quad \text { Curtis) Teng }\end{array}$ & $\begin{array}{l}\text { Methanol extract } \\
\text { Fractions: methylene } \\
\text { chloride, ethyl acetate, n- } \\
\text { butanol }\end{array}$ & - & $\begin{array}{l}\text { HUVECs; } \\
\text { Mice }\end{array}$ & $\begin{array}{l}\text { Inhibition of proliferation, } \\
\text { migration, tube formation and } \\
\text { VEGFR-2 phosphorylation }\end{array}$ & [129] \\
\hline $\begin{array}{l}\text { Pleurotus tuber-regium } \\
\quad \text { (Rumph. ex Fr.) Singer }\end{array}$ & $\begin{array}{l}\text { Ethanol extract } \\
\text { Fraction: ethyl acetate }\end{array}$ & $\begin{array}{l}\text { Chlorogenic acid and } \\
\text { syringic acid }\end{array}$ & $\begin{array}{l}\text { HUVECs } \\
\text { Zebrafish }\end{array}$ & $\begin{array}{l}\text { Inhibition of VEGF } \\
\text { Decrease of blood vessels } \\
\text { development }\end{array}$ & [130] \\
\hline
\end{tabular}

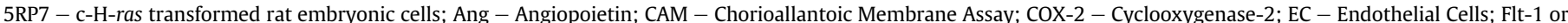

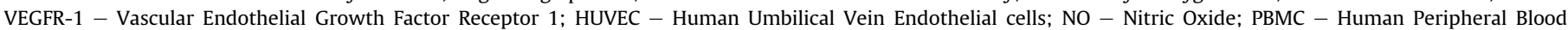

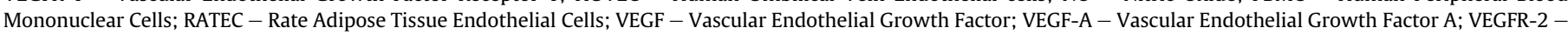
Vascular Endothelial Growth Factor Receptor 2. - Not specified or described.

macrophage cell line. The results suggested inhibition of vascular permeability and promotion of NO and COX-2 production. The antiangiogenic aptitude of the essential oil obtained from Origanum onites L. was evaluated by Bostancioğlu et al. [126]. The results show that this essential oil could markedly inhibit cell viability and induce apoptosis in 5RP7 cells and block formation and migration in rate adipose tissue endothelial cells (RATEC). Additionally, the oil demonstrated a higher toxicity against cancer cell (5RP7), comparatively with healthy cells. In the work developed by Kadria et al. [127], the antiangiogenic activity of neutral lipids, glycolipids and phospholipids, obtained from Pinus halepensis Mill. seeds, was evaluated in vitro using endothelial cells and in vivo using the CAM assay. Both assays pointed out for strong antiangiogenic activity through significant inhibition of blood vessels growth.

Some studies with mushroom extracts also reveal antiangiogenic properties. Nguyen et al. [128] studied ganoderic acid F, present in a methanolic extract of Ganoderma lucidum, and observed that ganoderic acid $\mathrm{F}$ have a potent inhibitory effect in the formation of capillary-like structures in HUVEC cells. Lee et al. [129] evaluated different fractions, obtained from Phellinus linteus methanolic extract. The results reveal several antiangiogenic related inhibitory effects, including inhibition of HUVEC cells proliferation, migration and assembly into capillary-like structures. They observed that the mechanism of action of the extracts occurred through inhibition of VEGFR-2 phosphorylation. Lin et al. [130] also studied an ethyl acetate fraction, obtained from the mushroom Pleurotus tuber-regium ethanolic extract. The ethyl acetate fraction demonstrated to be rich in phenolics, mainly chlorogenic and syringic acids. Using the zebrafish model, the ethyl acetate fraction was shown to inhibit blood vessels development and, using the HUVEC cells model, this fraction revealed ability to inhibit VEGF.

Some studies evaluated the anticancer effects of combined phenolic rich extracts or combined individual phenolic compounds, in order to overcome pathological angiogenesis. Mertens-Talcott et al. [131] combined quercetin with ellagic acid and the results showed a synergistic effect on proliferation reduction, viability and apoptosis activation in human leukemia cells (MOLT-4). MertensTalcott \& Percival [132] investigated the interactions of ellagic acid, quercetin and resveratrol and the results showed a high synergistic effect for the ellagic acid/resveratrol combination, in the induction of apoptosis and reduction of cell growth in MOLT-4 cells. Bagchi et al. [133] evaluated the in vitro and in vivo efficacy of a formulation composed by six anthocyanin-rich extracts (fruits of wild blueberry, bilberry, cranberry, elderberry, and strawberry, and from raspberry seeds) in antiangiogenic activity. In both in vitro and in vivo, the combined extracts suppressed important key regulators of angiogenesis such as TNF- $\alpha$ and VEGF in human keratinocytes, and significantly inhibited NF-kB in mouse hemangioendothelioma endothelial cells. Other studies developed by Zhou et al. [134] and Zhou et al. [135], evaluated in vivo the blend between tea and soy extracts observing the inhibition of angiogenesis, in prostate and 
breast cancer. A combined extract of clove, oregano, thyme, walnuts and coffee, proved to be a potent modulator of NF-kB signaling, both in vitro in a monocytic cell line, and in vivo in transgenic mice [136].

\subsection{Antiangiogenic potential of phenolic compounds}

Recently, many studies about phenolic compounds have been published and have portrayed a picture where they were shown to interfere, at a molecular level, with a large number of biological mechanisms [1]. Phenolic compounds were shown to have high affinity to molecular targets, as diverse as membrane receptors, protein transporters, transcriptions factors or through gene expression modulation [53]. Table 3 and Fig. 3 present an overview of the phenolic compounds that have been reported in the literature with antiangiogenic activities, through different mechanism/ effects of action.

Kim et al. [65,137], studied the antiangiogenic ability of two phenolic acids, caffeic and rosmarinic acids, in human retinal endothelial. The results showed that caffeic acid promotes inhibition of VEGF-induced proliferation, migration and tube formation, while rosmarinic acid showed cell cycle related inhibition of cell proliferation, related to increased levels of p21. Labrecque et al. [23] studied ellagic acid, having concluded that this phenolic acid inhibits phosphorylation of VEGFR-2 and PDGFR, in endothelial and smooth muscle cells, respectively.

Flavonoids are another group of phenolic compounds that have been extensively studied as potential chemopreventive agents. Acacetin was studied by Liu et al. [138] in ovarian cancer cells and showed a decrease in VEGF activation, through HIF- $1 \alpha$ inhibition and Akt activation; indicating that Akt and HIF- $1 \alpha$ are the essential downstream targets of acacetin for angiogenesis inhibition.

Apigenin is another flavonoid that has been extensively studied. A study performed by Zhao et al. [102], proved that apigenin exhibits cytotoxicity against human multiple myeloma cells, but not against normal peripheral blood mononuclear cells. These activities were related to proliferation inhibition and apoptosis induction in human multiple myeloma cells, through CK2 inhibition, Cdc37 reduction and Hsp90 phosphorylation. In a study performed by Banerjee and Mandal [139], two colorectal cell lines (HT-29 and HCT-15), were treated with apigenin and the results showed antiproliferative and apoptotic effects, together with the increase of

Table 3

Phenolic compounds from commercial sources with antiangiogenic activity.

\begin{tabular}{|c|c|c|c|c|}
\hline \multicolumn{2}{|c|}{ Phenolic compound } & \multirow{2}{*}{$\begin{array}{l}\text { Assay/Cells/Model } \\
\text { Human retinal endothelial cells }\end{array}$} & \multirow{2}{*}{$\begin{array}{l}\text { Mechanisms/effects of antiangiogenic action } \\
\text { Inhibition of VEGF-induced proliferation, migration and tube formation }\end{array}$} & \multirow{2}{*}{$\frac{\text { References }}{[137]}$} \\
\hline Phenolic acids & Caffeic acid & & & \\
\hline & Ellagic acid & BAECs & InhibitionVEGFR-2 phosphorylation & [23] \\
\hline & & Smooth muscle cells & Inhibition of VEGF and PDGF receptors phosphorylation & \\
\hline & Rosmarinic acid & Human retinal endothelial cells & $\begin{array}{l}\text { Inhibition of proliferation } \\
\mathrm{G}_{2} / \mathrm{M} \text { phase cell cycle arrest with increase of p } 21^{\text {WAF1 }}\end{array}$ & [65] \\
\hline \multirow[t]{19}{*}{ Flavonoids } & Acacetin & Ovarian cancer cells & $\begin{array}{l}\text { Decrease of VEGF transcriptional activation through HIF- } 1 \alpha \text { inhibition and } \\
\text { Akt activation }\end{array}$ & [138] \\
\hline & Apigenin & Human multiple myeloma cells & $\begin{array}{l}\text { Inhibition of CK2 kinase activity and reduction of Cdc37 and Hsp90 } \\
\text { phosphorylation }\end{array}$ & [102] \\
\hline & & Human colorectal cancer cells & Anti-proliferative and apoptotic effects & [139] \\
\hline & & & $\begin{array}{l}\text { Increase in p21 levels through a p53 independent pathway and inhibition of } \\
\text { cyclins E expression due to large amounts of the active p21and activation of } \\
\text { p16 down-regulated cyclin D1 }\end{array}$ & \\
\hline & & Human pancreatic cells & $\begin{array}{l}\text { Induction of cell apoptosis and inhibition of IKK- } \beta \text {-mediated NF-кB } \\
\text { activation }\end{array}$ & [140] \\
\hline & & Human pancreatic cancer cells & $\begin{array}{l}\text { Inhibition of the proliferation and migration through inhibition of HSP90/ } \\
\text { Cdc37 interaction }\end{array}$ & [68] \\
\hline & & $\mathrm{Z}^{\prime}$-Lyte ${ }^{\mathrm{TM}}$ Kinase assay Kit & Inhibition of VEGFR-2 activity & [123] \\
\hline & $\begin{array}{l}\text { Casticin and } \\
\text { chrysosplenol D }\end{array}$ & Rat peritoneal cells; PBMC & Suppression of NO, PGE 2 , and cytokines (VEGF, IL-1 $\beta$, IL-6 and TNF- $\alpha$ ) $\left(^{*}\right)$ & [121] \\
\hline & Epigallocatechin-3- & HUVECs & Interference with formation of VEGFR-2 complex & [141] \\
\hline & gallate (EGCG) & Human fibrosarcoma cell line & Inhibition of MMP-2 and MMP-9 & [27] \\
\hline & Genistein & Zebrafish & Reduction of VEGF expression & [143] \\
\hline & & Retinal cells & Reduction of HIF- $1 \alpha$ expression & {$[142]$} \\
\hline & & Intestinal epithelium & Inhibition of the activation of NF- $\kappa B$ and Akt signaling pathways & [43] \\
\hline & Kushecarpin D & HUVECS & $\begin{array}{l}\text { Inhibition of cell proliferation, migration, adhesion, and tube formation; } \\
\text { Ability to induce cell cycle arrest at the } \mathrm{G}_{2} / \mathrm{M} \text { phase }\left({ }^{*}\right)\end{array}$ & [144] \\
\hline & Luteolin & Human pancreatic cancer cells & $\begin{array}{l}\text { Anti-proliferative and apoptotic effects with significantly decreased protein } \\
\text { expression of nuclear GSK- } 3 \beta \text { and NF- } \kappa B\end{array}$ & [145] \\
\hline & & $\mathrm{Z}^{\prime}$-Lyte ${ }^{\mathrm{TM}}$ Kinase assay Kit & Inhibition of VEGFR-2 activity & [123] \\
\hline & Quercetin & HUVECs; & Inhibition of the VEGFR-2 expression; cell viability and tube formation & [146] \\
\hline & & Zebrafish & Disrupt formation of intersegmental vessels & \\
\hline & & Human lymphocytes & Inhibition of $\mathrm{COX}-2$ & [53] \\
\hline Phenylethanoid & Hydroxytyrosol & $\mathrm{EC}$ & $\begin{array}{l}\text { Inhibition of endothelial cell proliferation, migration and tube formation } \\
\text { Increase subG1 subpopulation }\end{array}$ & [147] \\
\hline & & & Decrease MMP2 expression & \\
\hline \multirow[t]{4}{*}{ Stilbenes } & Resveratrol & Capillary endothelial cells & Inhibition of VEGF and FGF receptors & [148] \\
\hline & & BAECs & Inhibition of proliferation, migration and tube formation & [149] \\
\hline & & Human adipose tissue & Inhibition of VEGF expression & [151] \\
\hline & & Retinal pigment epithelium & Inhibition of HIF- $1 \alpha$ and VEGF expression & [150] \\
\hline
\end{tabular}

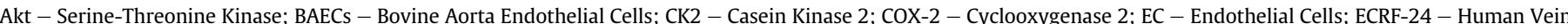

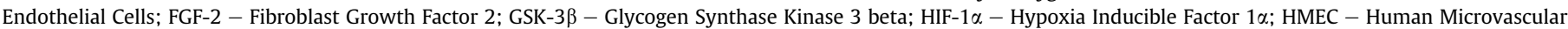

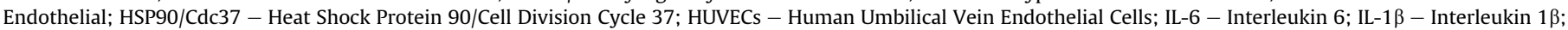

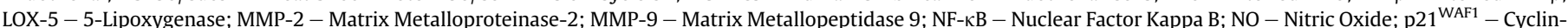

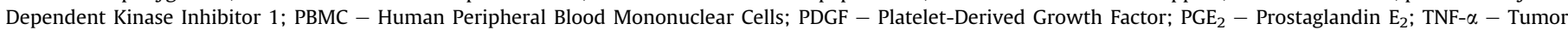

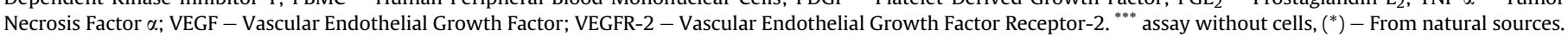


<smiles>O=C(O)/C=C/c1ccc(O)c(O)c1</smiles>

Caffeic acid<smiles>O=c1oc2c(O)c(O)cc3c(=O)oc4c(O)c(O)cc1c4c23</smiles>

Ellagic acid<smiles>O=C(/C=C/c1ccc(O)c(O)c1)O[C@H](Cc1ccc(O)c(O)c1)C(=O)O</smiles>

Rosmarinic acid<smiles>COc1ccc(-c2cc(=O)c3c(O)cc(O)cc3o2)cc1</smiles>

Acacetin

Apigenin

$$
\text { Casticin }
$$<smiles>COc1cc2oc(-c3ccc(O)c(O)c3)c(OC)c(=O)c2c(O)c1OC</smiles>

Chrysosplenol D<smiles>COc1ccc2c(c1)O[C@H]1[C@@]3(O)C=CC(=O)C=C3OC[C@]21O</smiles>

Kushecarpin D<smiles>O=c1cc(-c2ccc(O)c(O)c2)oc2cc(O)cc(O)c12</smiles>

Luteolin<smiles>O=c1c(O)c(-c2ccc(O)c(O)c2)oc2cc(O)cc(O)c12</smiles>

Quercetin<smiles>OCCc1ccc(O)c(O)c1</smiles>

Hydroxytyrosol<smiles>Oc1ccc(/C=C/c2cc(O)cc(O)c2)cc1</smiles>

Resveratrol

Fig. 3. Phenolic compounds with antiangiogenic activity. 
p21 levels and inhibition of cyclins E and D1. In pancreatic cells, different targets of apigenin were observed and this flavonoid was shown to interfere with cell proliferation, apoptosis and migration effects through different mechanism, including inhibition of IKK- $\beta$, NF- $\kappa B$ activation [140] and by HSP90/Cdc37 inhibition [68]. Finally, Guimarães et al. [123] demonstrated, by using an enzymatic assay, that apigenin was able to inhibit VEGFR-2.

Two flavonoids, casticin and chrysosplenol D, were extracted from Arteminisia annua L. and studied for their antiangiogenic proprieties by Zhu et al. [121]. This study showed that these flavonoids are involved in the suppression of various molecules associated to the angiogenesis process, including NO, PGE2, VEGF, IL-1 $\beta$, IL- 6 and TNF- $\alpha$, both in rat peritoneal cells and human peripheral blood mononuclear cells.

Epigallocatechin-3-gallate (EGCG) is a flavonoid abundantly found in green tea, that has shown significant antioxidant and anticancer activity. Rodriguez et al. [141] reported that ECGC inhibits the formation of the VEGFR dimer, a process that is essential in VEGF angiogenesis signaling. Maeda-Yamamoto et al. [27] reported another effect of EGCG, in human fibrosarcoma cells, where metastasis development was inhibited by EGCG binding to the matrix metalloenzymes MMP-2 and MMP-9.

Wang et al. [142], Rathinasamy et al. [143] and Ruiz and Haller [43] studied the effects of genistein in angiogenesis and verified, respectively, a decrease in VEGF expression and consequent inhibition of regenerative caudal find in zebrafish, a decrease in HIF- $1 \alpha$ expression in retinal cells and an inhibition of $\mathrm{NF}-\kappa \mathrm{B}$ and Akt signaling pathways in intestinal epithelium.

Kushecarpin D is a recently discovered flavonoid, isolated from the dried root of Sophora flavescens A., a plant known as a medicinal herb. In a study developed by Pu et al. [144], the antiangiogenic properties of Kushecarpin D were examined in vitro using HUVEC cells. The results indicate that this flavonoid showed antiangiogenic activity, via inhibitory effects on cell proliferation, cell migration, cell adhesion, and tube formation and the ability to induce cell cycle arrest at G2/M phase.

Luteolin is another flavonoid abundantly found in various food sources, its antiangiogenic properties were studied by Johnson and Mejia [145] and Guimarães et al. [123]. These works revealed interference in the angiogenesis at a molecular level, including, inhibition of the NF-kB signaling pathway in human pancreatic cancer cells, and VEGFR-2 activity inhibition.

To finalize the flavonoid group, Zhao et al. [146] investigated the antiangiogenic activity of quercetin, both with zebrafish model and HUVEC cells. Quercetin was shown to disrupt the formation of the intersegmental vessels, the dorsal aorta and the posterior cardinal vein in transgenic zebrafish model; and was shown to inhibit cell viability, VEGFR-2 expression and tube formation in HUVEC cells. Thus, quercetin was shown to be involved in suppressing, both in vivo and in vitro, the extracellular signal-regulated VEGFR-2 signaling pathway. Inflammation is a process that is tightly linked with angiogenesis, especially in conditions like rheumatoid arthritis. Pascual-Teresa et al. [53] studied the potential of quercetin to stagnate inflammation, by inhibition of COX-2 transcription, and demonstrated that quercetin metabolites were able to downgrade COX-2 expression.

Fortes et al. [147] investigated the antiangiogenic potential of hydroxytyrosol, a phenolic compound found in virgin olive oil, in three different types of endothelial cells including, bovine aorta endothelial cells (BAEC), umbilical vein endothelial cells (ECRF-24) and human microvascular endothelial cells (HMEC). This phenolic compound displayed a diverse set of action mechanisms related to angiogenesis inhibition. Hydroxytyrosol was shown to inhibit proliferation, migration and tube formation in the studied endothelial cells; it affects cell cycle by a remarkable increase in the subG1 subpopulation, which is indicative of apoptotic cells; and also decreases the MMP-2 mediated invasive potential of endothelial cells.

Resveratrol is the best studied phenolic compound from the stilbenes group. Bråkenhielm et al. [148] demonstrated the ability of resveratrol to inhibit capillary endothelial cell growth and this inhibition was related to the inhibition of both FGFR and VEGFR angiogenesis signaling pathway, thru suppression of MAP Kinase phosphorylation. In a work developed by Igura et al. [149], resveratrol was shown to inhibit proliferation, migration and tube formation in BAECs, although the exact molecular mechanism of action was not studied. Zhang et al. [150] verified that resveratrol significantly inhibited HIF- $1 \alpha$ and VEGF expression, under hypoxia conditions. Another study performed by Cullberg et al. [151] also verified the ability of resveratrol to inhibit key factors in hypoxia conditions in human adipose tissue, specifically it was observed that resveratrol inhibited VEGF expression.

In general, the phenolic compounds have shown significant antiangiogenic properties, and are certainly worth a closer look for the possible development of new therapies against pathological and tumor angiogenesis.

\subsection{Antiangiogenic potential of other natural compounds}

Phenolic compounds are the most extensively studied natural compounds for their antiangiogenic properties. However, other compounds, obtained from natural sources, have demonstrated effectiveness as angiogenesis inhibitors, including alkaloids and terpenoids (Table 4 and Figs. 4-6), and have also become important topics of study concerning cancer prevention through inhibition of angiogenesis.

Pterogynidine is an alkaloid that showed strong antiangiogenic effects in HUVEC cells. The results demonstrated that this alkaloid drastically reduced capillary-like structures formation and its activity was related to NF-kB inhibition [152]. Punarnavine is another alkaloid that was shown to inhibit neovascularization in sponge implant model, using Ehrlich ascites carcinoma model, by suppressing VEGF expression. Using HUVECs cells, punarnavine also demonstrated inhibition ability of MMP-2 and MMP-9 expression [153]. In another study, Manu \& Kuttan [77] proved the antiangiogenic properties of punarnavine in B16F-10 melanoma cells in mice, by supressing or down regulating the expression of MMP-2, MMP-9, ERK and VEGF. Zhao et al. [154] studied the antiangiogenic potential of total alkaloids present in Rubus alceifolius poir extract; briefly, the study demonstrated that these compounds inhibit pathological angiogenesis, through suppression of microvessel, via reducing VEGF expression; and HUVECs cell replication, by blocking cell cycle $\mathrm{G} 1$ to $\mathrm{S}$ progression. The results were confirmed in vivo using the CAM model.

In the terpenoid group, various compounds showed antiangiogenic potential. Aescin or $\beta$-escin (see Fig. 5), a major active compound in horse chestnut extract, was able to inhibit angiogenesis, using the HUVEC cell model and the CAM assay. At a molecular level, aescin was shown to inhibit angiogenesis by increasing expression of thrombospondin-1 (TSP-1) and by decreasing expression of protein kinase C $-\alpha$ (PKC- $\alpha)$ [79].

Other class of terpenoids with antiangiogenic potential are carotenoids (see Fig. 6). Ganesan et al. [155] studied the antiangiogenic potential, and the mechanism of action, of two algal carotenoids (fucoxanthin and siphonaxanthin), using the HUVEC cell model. This study showed that both carotenoids suppress FGF2 expression. Furthermore, the antiangiogenic inhibition ability of total carotenoids ( $\beta$-carotene, $\beta$-cryptoxanthin, lutein, zeaxanthin and retinoic acid), present in maize extract, was established, using 
Table 4

Other natural compounds with antiangiogenic potential.

\begin{tabular}{|c|c|c|c|c|}
\hline \multicolumn{2}{|c|}{ Natural compound } & \multirow{2}{*}{$\begin{array}{l}\text { Assay/Cell/Model } \\
\text { HUVECs }\end{array}$} & \multirow{2}{*}{$\begin{array}{l}\text { Mechanism/effects of antiangiogenic action } \\
\text { Reduction of NF-kB activity }\end{array}$} & \multirow{2}{*}{$\frac{\text { Reference }}{[152]}$} \\
\hline Alkaloids & Pterogynidine & & & \\
\hline & Punarnavine & HUVECS & Inhibition of MMP-2 and MMP-9 expression & [153] \\
\hline & & Ehrlich ascites carcinoma tumor & Downregulation of VEGF expression & \\
\hline & & B16F-10 melanoma cells & $\begin{array}{l}\text { Downregulation of MMP-2 and MMP-9, } \\
\text { ERK, VEGF expression }\end{array}$ & [77] \\
\hline & - & HUVECs and CAM & $\begin{array}{l}\text { Blocking of cell cycle G1/S and inhibition of } \\
\text { VEGF }\end{array}$ & [154] \\
\hline \multirow[t]{13}{*}{ Terpenoids } & Aescin & HUVECS and CAM & $\begin{array}{l}\text { Increase expression of TSP-1, and decrease } \\
\text { expression of PKC- } \alpha\end{array}$ & [79] \\
\hline & Carotenoids & HUVECs & Suppression of FGF-2 expression & [155] \\
\hline & & YSM and CAM & - & [156] \\
\hline & Celastrol & Human glioma cells & Suppression of VEGFR expression & [157] \\
\hline & & $\begin{array}{l}\text { Human lung carcinoma (H1299), human embryonic kidney } \\
\text { (A293), human multiple myeloma (U266) and bladder } \\
\text { cancer (253JBV) cell line }\end{array}$ & $\begin{array}{l}\text { Inhibition of TNF-induced and NF-kB } \\
\text { activation }\end{array}$ & [158] \\
\hline & Escins Ia, Ib, IIa and IIb & In mice models & - & [159] \\
\hline & Furanodiene & HUVECs and zebrafish embryos & Inhibition of VEGF and suppression of Akt & [160] \\
\hline & Polyphyllin D & $\begin{array}{l}\text { Human microvascular endothelial cell line (HMEC-1) and } \\
\text { Zebrafish embryos }\end{array}$ & - & [161] \\
\hline & Withaferin A & $\begin{array}{l}\text { Caski human cervical cancer cell line and human hepatoma } \\
\text { (SK-Hep1) cells }\end{array}$ & Inhibition of MMP-9 activity & [163] \\
\hline & & HUVECs and CAM & Suppression of VEGF expression & [162] \\
\hline & & \# $\quad$ - n & Inhibition of VEGF & [164] \\
\hline & & HUVECS & Inhibition of NF-kB & [165] \\
\hline & Withanone and Withaferin A & HUVECs and nude mice & Downregulation of VEGF and MMP & [166] \\
\hline
\end{tabular}

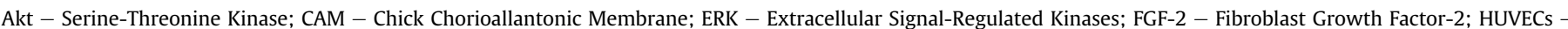

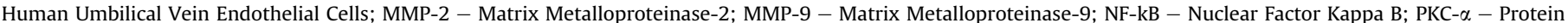

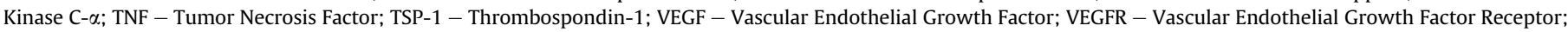
YSM - Chick Yolk Sac Membrane; - Not specified or described; \# - not used cells, only molecular docking studies.

the chick yolk sac membrane (YSM) and CAM assays [156]. The results showed that this extract was an interesting source of carotenoids, which effectively inhibited the formation of new vessels. Celastrol (see Fig. 4) is a terpenoid that demonstrated antiangiogenic effects, by suppression of VEGFR expression in human glioma cells, consequently reducing the signal transduction between VEGF and VEGFR, thus inhibiting endothelial cell proliferation, migration and differentiation [157]. Other studies proved that celastrol inhibits angiogenesis through an alternative mechanism, by inhibiting TNF- $\alpha$-induced activation of the NF-kB complex [158]. Escins Ia, Ib, Ila and IIb (see Fig. 5), obtained from natural sources, proved their potential to inhibit the increase of vascular permeability in mice models [159]. Furanodiene (see Fig. 4) is an active ingredient found in various plants, which was shown to inhibit angiogenesis in HUVEC cells model, through inhibition of VEGF. These results were confirmed using the zebrafish model. Furanodiene was also shown to suppress expression of Akt kinase [160].

Polyphyllin D was another terpenoid studied for its antiangiogenic potential. This compound displayed in vitro angiogenesis inhibition, by suppressing cell proliferation, migration and tube formation; and in vivo angiogenesis inhibition by the ability to impair intersegmental vessels formation in zebrafish embryos [161].

An extensive study was performed on the antiangiogenic potential of withaferin A [162]. This terpenoid showed ability to block cell invasion and migration in Caski human cervical cells and in hepatoma SK-Hep1 cells. This activity was linked to the ability of withaferin A to decrease MMP-9 activity [163]. Withaferin A also demonstrated ability to block tube formation in HUVEC cells and in the CAM assay. This angiogenesis inhibition ability was related to direct inhibition of VEGF [162]. The hypotheses that withaferin A promotes angiogenesis inhibition, thru VEGF direct inhibition, was further demonstrated using a molecular docking approach. In this study, a rational interaction mode between withaferin A and VEGF was presented [164]. An alternative mechanism of action of withaferin A, obtained from Withania somnifera, was also presented by another study, where withaferin A was shown to inhibit NF-kB activity in HUVEC cells [165]. Additionally, Gao et al. [166], studied the combination of withanone and withaferin $A$, verifying that this combination showed significant antimigratory and antiangiogenic activities, both in vitro or in vivo assays. Furthermore, the authors demonstrated, by using bioinformatic and biochemical approaches, that withanone and withaferin A caused downregulation of VEGF and MMPs.

Taken together, all the reviewed studies demonstrate that there are several compounds, obtained from natural sources, which can be considered for antiangiogenic therapy, or as new drugs for the development of chemically-related and even more potent antiangiogenic compounds. As so, this review synopsizes important knowledge based on the current state of the art of naturally occurring angiogenesis inhibitors.

\section{Future challenges}

Due to their remarkable chemical variety, natural compounds have attracted considerable attention as potential candidates for therapeutic use against different pathologies. Special attention has been payed to naturally occurring anticancer agents, and respective derivatives, and in the study of the multiple pathways involved in cancer development [167]. Angiogenesis is an essential process involved in several diseases, including tumor-associated angiogenesis. Although angiogenesis is considered a relevant target for the prevention and treatment of many disorders, the bulk of the research done so far is focused on tumor angiogenesis, and, as a consequence, clinically available antiangiogenic drugs are all targeted to tumor angiogenesis [47,168]. Current antiangiogenic drugs are limited in number, expensive and have shown to induce serious side effects (Table 1 and Fig. 2). The search for natural products and natural molecules as potential antiangiogenics, with less toxicity 
<smiles>CC(C)CCNC(=N)NCCC(C)C</smiles>

Pterogynidine

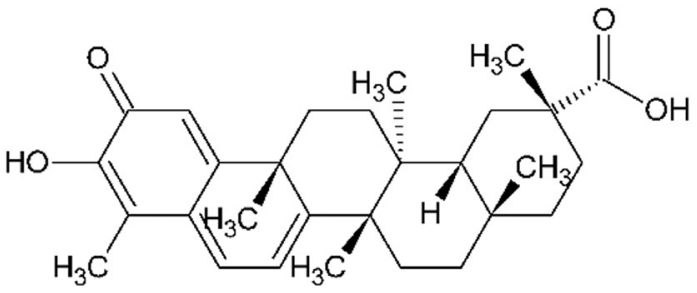

Celastrol<smiles>COc1ccc2c(=O)cc(-c3ccc4c(c3)OCO4)n(C)c2c1</smiles>

Punarnavine<smiles>CC1=CCc2c(C)coc2CC(C)=CCC1</smiles>

Furanodiene

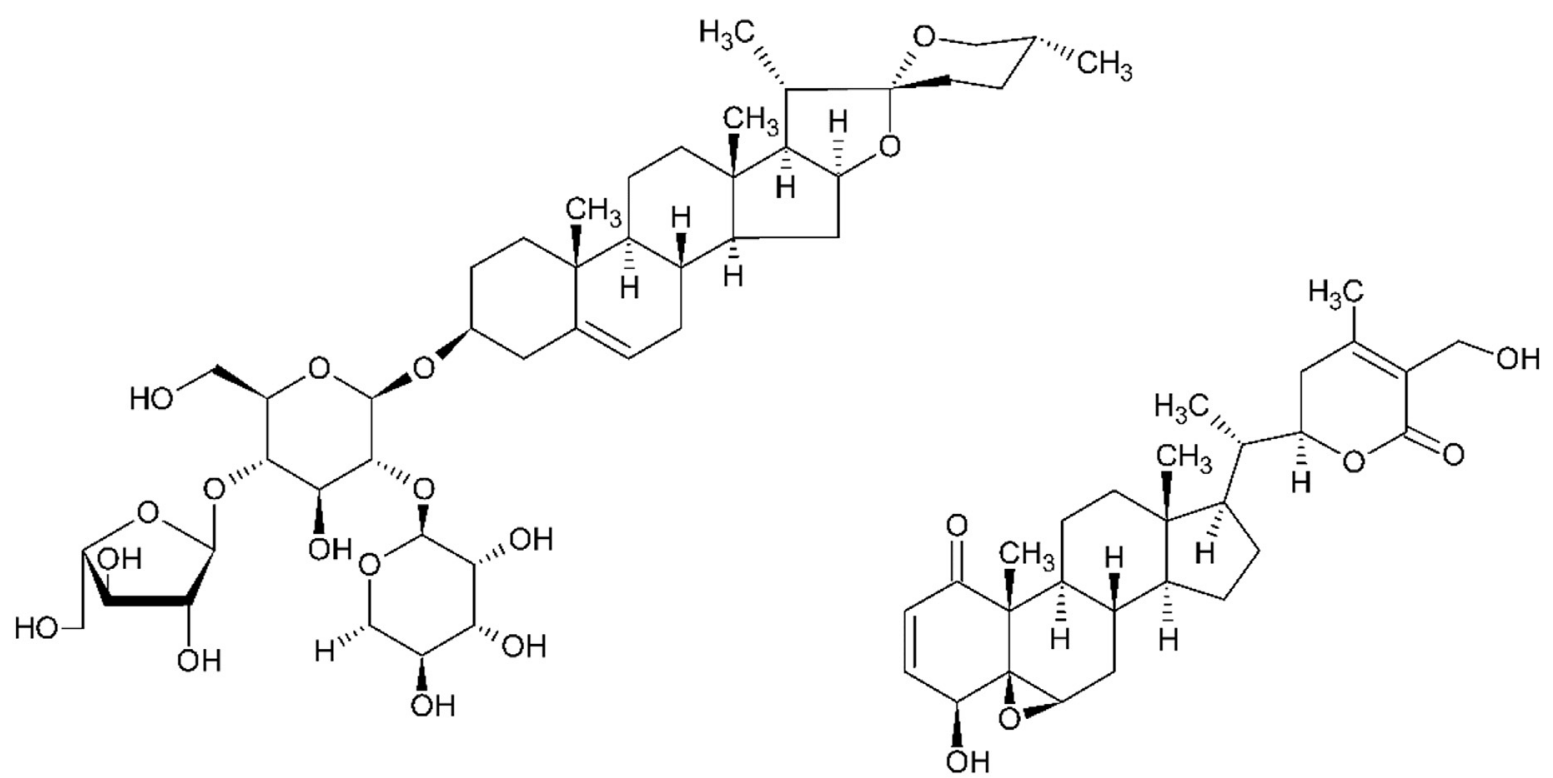

Polyphyllin D

Withaferin A

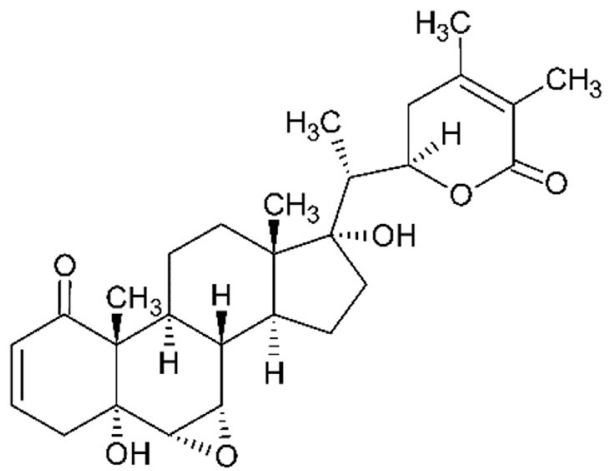

Withanone

Fig. 4. Alkaloids and terpenoids with antiangiogenic activity. 


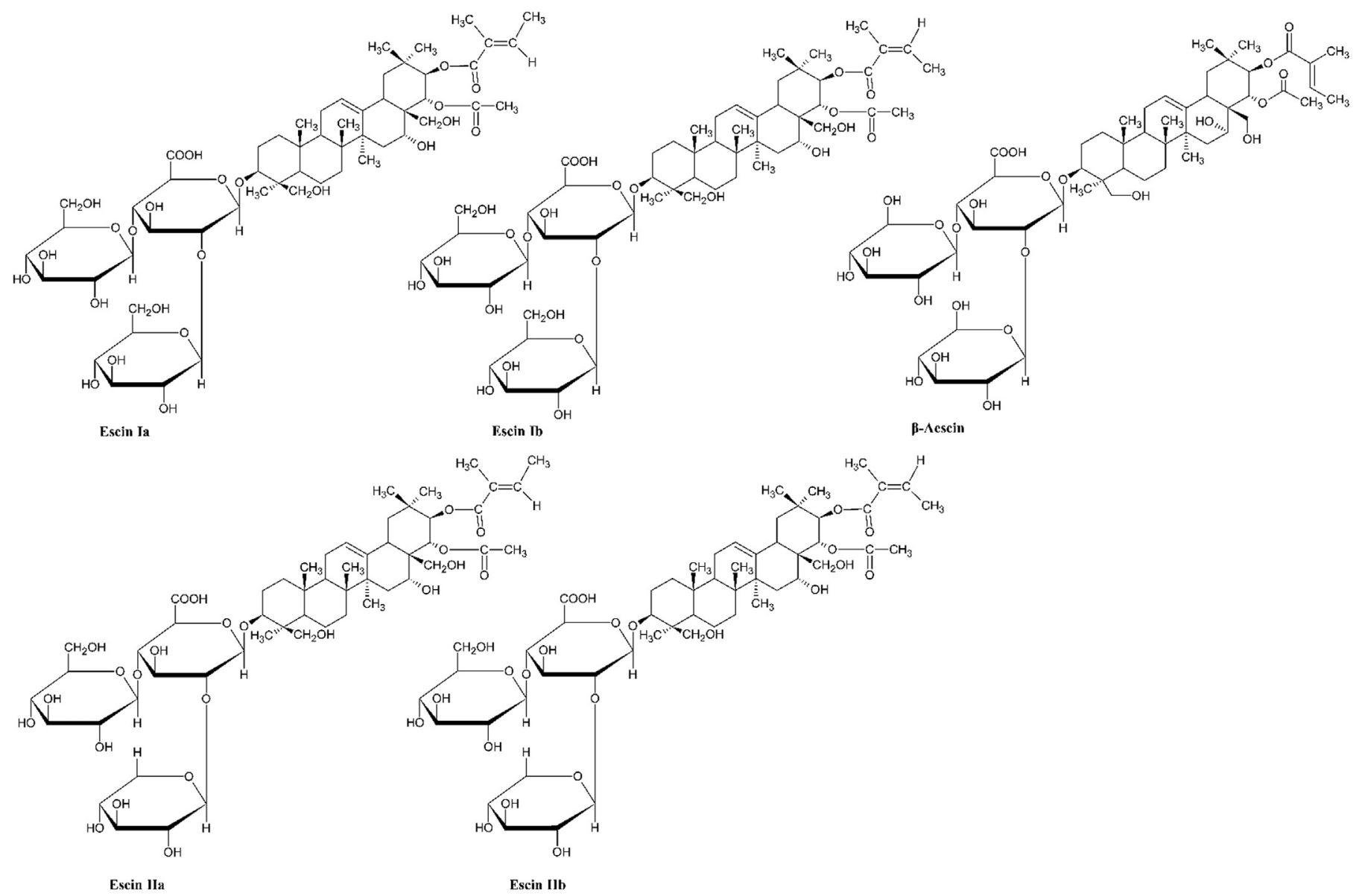

Fig. 5. Different escins (terpenoids) with antiangiogenic activity.

and at competitive prices, is thus the obvious next step in antiangiogenic therapy [115]. This review describes a wide variety of natural extracts and molecules (Tables 2-4 and Figs. 3-6) with angiogenic modulation ability and, when relevant information is available, the molecular mechanisms underlying the respective activity are discussed. When comparing the small number of proteins targeted by current antiangiogenic drugs, with the large number of molecular pathways involved in the complex mechanism of angiogenesis, it is clear to draw the conclusion that there is still considerable work to be done in order to find better and more diverse antiangiogenic drugs, and natural sources urge to be explored due to their chemical diversity [47].

The main advantage of natural products, relies on their ability to be more acceptable to patients, thus more adequate to be administered orally. As shown in Tables 2-4, natural compounds present various mechanisms in order to target angiogenesis. Furthermore, these natural molecules exhibit antiangiogenic activity identical to the synthetically drugs currently in clinical use [47]. In this sense, Chatterjee \& Bhattacharjee [167] compared the performance of epigallocatechin gallate and the drug pazopanib, as VEGFR-2 inhibitors. The results showed similar effectiveness of the two compounds. Furthermore, the use of phenolic compounds individually, or combined, has shown to diminish synthetic drugs resistance and may have therapeutic potential for a broader range of tumor diseases [47].

In spite of the current context, there are still problems that need to be overcome, to generalize the use of natural compounds in clinical practice against different pathologies [115]. The main problems are related to bioavailability, bioefficacy and biostability issues, since many natural compounds exhibit low solubility and low absorption rates. Therefore, only a small amount of the ingested dose reaches the circulation and the desired target location [115]. Microencapsulation constitutes a possible technique that may help to surpass these constraints, ensuring a better deliver of natural compounds to the desired tissue target. Through microencapsulation, natural compounds are incorporated into polymer matrices enabling better protection [169]. Such processes help to guarantee the activity of the natural compounds, and to improve targeting to the desired location [170]. Several studies, conducted to microencapsulate phenolic compounds, showed enhanced antiangiogenic effects of these forms [170-172]. Another strategy to increase the bioavailability, efficacy and stability is discussed by Wang et al. [47] and Lu et al. [115] consisting on chemical derivatization. Chemical derivatization also called as chemical modification correspond at a transformation of chemical compound in another compound by changing one or more functional groups in order to modify the specific characteristics. In this sense, the main objective is altering reactivity or properties such as solubility, thermal stability, among others. Thus, with this approach, functional groups are added or removed to the phenolic compounds, improving its pharmacokinetic profile [47]. The principal objective of these modifications is increasing the bioactivity of the phenolic compounds and consequently problems, such as absorption, can be overcome and thus favoring their interaction with the specific molecules of pathological angiogenesis blocking the reaction chain. However, these technologies such as microencapsulation or 
<smiles>CC(=O)OC1CC(C)(C)C(=C=CC(C)=CC=CC(C)=CC=CC=C(C)C=CC=C(C)C(=O)C[C@@]23O[C@]2(C)C[C@@H](O)CC3(C)C)[C@@](C)(O)C1</smiles><smiles>CC1=C[C@@H](O)CC(C)(C)[C@H]1/C=C/C(C)=C/C=C/C(C)=C/C=C/C=C(C)/C=C/C=C(\CO)C(=O)C[C@H]1[C@@H](C)C[C@@H](O)CC1(C)C</smiles>

Siphonaxanthin<smiles>CC1=C(/C=C/C(C)=C/C=C/C(C)=C/C=C/C=C(C)/C=C/C=C(C)/C=C/C2=C(C)CCCC2(C)C)C(C)(C)CCC1</smiles>

\section{p-carotene}<smiles>CC1=C(/C=C/C(C)=C/C=C/C(C)=C/C=C/C=C(C)/C=C/C=C(C)/C=C/C2=C(C)C[C@@H](O)CC2(C)C)C(C)(C)CCC1</smiles>

\section{B-cryptoxanthin}<smiles>CC1=C[C@@H](O)CC(C)(C)C1/C=C/C(C)=C/C=C/C(C)=C/C=C/C=C(C)/C=C/C=C(C)/C=C/C1=C(C)C[C@@H](O)CC1(C)C</smiles>

Lutein<smiles>CC1=C(/C=C/C(C)=C/C=C/C(C)=C/C=C/C=C(C)/C=C/C=C(C)/C=C/C2=C(C)C[C@@H](O)CC2(C)C)C(C)(C)C[C@H](O)C1</smiles>

Zeaxanthin<smiles>CC1=C(/C=C/C(C)=C/C=C/C(C)=C\C(=O)O)C(C)(C)CCC1</smiles>

\section{Retinoic acid}


chemical derivations applied in natural compounds require further studies in order to optimize the antiangiogenic effect.

Pathological angiogenesis occurs when an imbalance of endogenous proangiogenic and antiangiogenic factors occurs. Although the focus of angiogenesis-related drug development has been geared to the discovery of antiangiogenic compounds for use in pathologies where excessive angiogenesis occurs (cancer, rheumatoid arthritis, retinopathy to name a few), an increase interest has been directed towards the development of proangiogenic drugs for use in pathologies were insufficient angiogenesis occurs (coronary heart disease, stroke, chronic wounds to name a few) [173]. Given that a number of natural compounds have exhibited proangiogenic activity, the approach of explore these compounds in such applications configures a promising field of research [115].

\section{Concluding remarks}

All cells need a steady supply of oxygen, nutrients and a way to remove waste materials, and this is accomplished by an efficient network by blood vessels. Angiogenesis is a biological process through which new blood vessels are formed and is essential for various biological processes. Pathological angiogenesis is related with the development of various and serious diseases, particularly cancer. In this case, the angiogenesis is very important for development, survival and metastases formation. Angiogenesis is very complex and involves different and numerous angiogenic factors and signaling pathways, including growth factors, MMP, cytokines, arachidonic acid derivatives, transcription factors and cell cycle related proteins among others. VEGF and his membrane receptor is the most studied growth factor. Several antiangiogenic drugs have been developed, and bevacizumab was the first one to be used in therapies applied in vivo to tumor angiogenesis. Still, due to toxicity and cost constraints of these drugs, the development of new treatments is becoming highly important. In this context, natural bioactive compounds, present in various natural products, have shown high antiangiogenic capacity together with well-being effects. Compared with currently available antiangiogenic drugs, plant-derived products may not only have similar therapeutic potential, presenting also clear advantages due to their lower toxicity and ease way of administration. Also, they can be regarded as inexpensive solutions, when compared with synthetic counterparts. The approach of applying natural compounds in the treatment to angiogenesis-related pathologies is, therefore, a promising field of research. However, novel and effective strategies are necessary to improve their bioavailability for clinical use.

\section{Conflicts of interest}

The authors declare that they have no conflicts of interest.

\section{Acknowledgements}

POCI-01-0145-FEDER-006984 (LA LSRE-LCM), funded by FEDER, through POCI-COMPETE2020 and FCT; Project NORTE-01-0145FEDER-000006, funded by NORTE2020 under the PT2020, through ERDF; FCT and ERDF under PT2020 for financial support to CIMO (UID/AGR/00690/2013). Andreia Ribeiro acknowledges her PhD fellowship funded by Project NORTE-08-5369-FSE-000028, supported by N2020, under PT2020, through ESF.

\section{References}

[1] Q. Sun, J. Heilmann, B. Kõning, Natural phenolic metabolites with antiangiogenic properties - a review from the chemical point of view, J. Org. Chem. 11 (2015) 249-264.
[2] P. Carmeliet, Angiogenesis in health and disease, Nat. Med. 9 (2003) 653-660.

[3] G. Gao, M. Li, Y. Lv, S. Cao, L. Tong, L. Wei, J. Ding, H. Xie, W. Duan, Design, synthesis and biological evaluation of biphenylurea derivatives as VEGFR-2 kinase inhibitors (II), Chin. Chem. Lett. (2015), https://doi.org/10.1016/ j.cclet.2015.10.004

[4] N. Ferrara, R.S. Kerbel, Angiogenesis as a therapeutic target, Nature 438 (2005) 967-974.

[5] T.H. Adair, J.P. Montani, Angiogenesis, Morgan \& Claypool Life Sciences, San Rafael (CA), 2010.

[6] R.J. Tomanek, Angiogenesis and cardiovascular diseases, in: J.N. Losso, F. Shahidi, D. Bagchi (Eds.), Anti-angiogenic Functional and Medicinal Foods, first ed., CRC Press, 2007, pp. 441-452.

[7] S. Mandal, S.K. Kundu-Raychaudhuri, S.P. Raychaudhuri, Angiogenesis in inflammatory arthritis, in: J.N. Losso, F. Shahidi, D. Bagchi (Eds.), Antiangiogenic Functional and Medicinal Foods, first ed., CRC Press, 2007, pp. $403-439$.

[8] A. Garofalo, A. Farce, S. Ravez, A. Lemoine, P. Six, P. Chavatte, L. Goossens, P. Depreux, Synthesis and structure-activity relationships of (aryloxy) quinazoline ureas as novel, potent, and selective vascular endothelial growth factor receptor-2 inhibitors, J. Med. Chem. 55 (2012) 1189-1204.

[9] K. Sanphanya, S.K. Wattanapitayakul, S. Phowichit, V.V. Fokin, O. Vajragupta, Novel VEGFR-2 kinase inhibitors identified by the back-to-front approach, Bioorg. Med. Chem. Lett. 23 (2013) 2962-2967.

[10] H. Gao, P. Su, Y. Shi, X. Shen, Y. Zhang, J. Dong, J. Zhang, Discovery of novel VEGFR-2 inhibitors. Part II: biphenyl urea incorporated with salicylaldoxime, Eur. J. Med. Chem. 90 (2015) 232-240.

[11] V. Baeriswyl, G. Christofori, The angiogenic switch in carcinogenesis, Semin. Cancer Biol. 19 (2009) 329-337.

[12] A. Ebadi, N. Razzaghi-Asl, S. Shahabipour, R. Miri, Ab-initio, Conformational, Analysis of a potent VEGFR-2 inhibitor: a case study on Motesanib, Iran. J. Pharm. Res. 13 (2014) 405-415.

[13] N. Ferrara, H.P. Gerber, J. LeCouter, The biology of VEGF and its receptors, Nat. Med. 9 (2003) 669-676.

[14] B. Escudier, T. Eisen, W.M. Stadler, C. Szczylik, S. Oudard, M. Siebels S. Negrier, C. Chevreau, E. Solska, A.A. Desai, F. Rolland, T. Demkow, T.E. Hutson, M. Gore, S. Freeman, B. Schwartz, M. Shan, R. Simantov, R.M. Bukowski, Sorafenib in advanced clear-cell renal-cell carcinoma, New Engl. J. Med. 356 (2007) 125-134.

[15] R.J. Motzer, E. Basch, Targeted drugs for metastatic renal cell carcinoma, Lancet 370 (2007) 2071-2073.

[16] L. Shi, T.T. Wu, Z. Wang, J.Y. Xue, Y.G. Xu, Discovery of N-(2-phenyl-1H-benzo [d] imidazol-5-yl)quinolin-4-amine derivatives as novel VEGFR-2 kinase inhibitors, Eur. J. Med. Chem. 84 (2014) 698-707.

[17] J. Zhang, Y. Shan, X. Pan, L. He, Recent advances in antiangiogenic agents with VEGFR as target, Mini Rev. Med. Chem. 11 (2011) 920-946.

[18] A. Duvoix, R. Blasius, S. Delhalle, M. Schnekenburger, F. Morceau, E. Henry, M. Dicato, M. Diederich, Chemopreventive and therapeutic effects of curcumin, Cancer Lett. 223 (2005) 181-190.

[19] U. Lewandowska, S. Gorlach, K. Owczarek, E. Hrabec, K. Szewczyk, Synergistic interactions between anticancer chemotherapeutics and phenolic compounds and anticancer synergy between polyphenols, Postepy Hig. Med. Dosw. 68 (2014) 528-540.

[20] J.N. Losso, Screening functional foods as inhibitors of angiogenesis biomarkers, in: J.N. Losso, F. Shahidi, D. Bagchi (Eds.), Anti-angiogenic Functional and Medicinal Foods, first ed., CRC Press, 2007, pp. 507-525.

[21] S. Shen, X. Xu, Z. Liu, J. Liu, L. Hu, Synthesis and structure-activity relationships of boswellic acid derivatives as potent VEGFR-2 inhibitors, Bioorg. Med. Chem. 23 (2015) 1982-1993.

[22] N.G. Gavalas, M. Liontos, S. Trachana, T. Bagratuni, C. Arapinis, C. Liacos M.A. Dimopoulos, A. Bamias, Angiogenesis-related pathways in the pathogenesis of ovarian cancer, Inter. J. Mol. Sci. 14 (2013) 15885-15909.

[23] L. Labrecque, S. LAmy, A. Chapus, S. Mihoubi, Y. Durocher, B. Cass, M.W. Bojanwski, D. Gingras, R. Béliveau, Combined inhibition of PDGF and VEGF receptors by ellagic acid, a dietary-derived phenolic compound, Carcinogenesis 26 (2005) 821-826.

[24] C.T. Rodríguez, M.T. Portolés, M.C. Matesanz, J. Linares, M.J. Feito I. Izquierdo-Barba, P. Esbrit, M. Vallet-Regí, Effects of bleaching on osteoclast activity and their modulation by osteostatin and fibroblast growth factor 2 , J. Colloid Interface Sci. 461 (2016) 285-291.

[25] A.A. Ucuzian, A.A. Gassman, A.T. East, H.P. Greisler, Molecular mediators of angiogenesis, J. Burn Care Res. 31 (2010) 158-175.

[26] A. Moss, The angiopoietin:Tie 2 interaction: a potential target for future therapies in human vascular disease, Cytokine Growth Factor Rev. 24 (2013) 579-592.

[27] M. Maeda-Yamamoto, H. Kawahara, N. Tahara, K. Tsuji, Y. Hara, M. Isemura, Effects of tea polyphenols on the invasion and matrix metalloproteinases activities of human fibrosarcoma HT1080 cells, J. Agric. Food Chem. 47 (1999) 2350-2354.

[28] R. Visse, H. Nagase, Matrix metalloproteinases and tissue inhibitors of metalloproteinases, Circ. Res. 92 (2003) 827-839.

[29] Y. Cao, R. Cao, E. Hedlund, Regulation of tumor angiogenesis and metastasis by FGF and PDGF signaling pathways, J. Mol. Med. 86 (2008) 785-789.

[30] T. Behl, A. Kotwani, Possible role of endostatin in the antiangiogenic therapy of diabetic retinopathy, Life Sci. 135 (2015) 131-137. 
[31] C. Hagemann, J. Anacker, R.I. Ernestus, G.H. Vince, A complete compilation of matrix metalloproteinase expression in human malignant gliomas, World $\mathrm{J}$. Clin. Oncol. 3 (2012) 67-79.

[32] M.D. Turner, B. Nedjai, T. Hurst, D.J. Pennington, Cytokines and chemokines: at the crossroads of cell signalling and inflammatory disease, Biochim. Biophys. Acta 1843 (2014) 2563-2582.

[33] A. Mantovani, F. Bussolino, E. Dejana, Cytokine regulation of endothelial cell function, FASEB J. 6 (1992) 2591-2599.

[34] D.N. Granger, E. Senchenkova, Angiogenesis, in: D.N. Granger, E. Senchenkova (Eds.), Inflammation and the Microcirculation, first ed., Morgan \& Claypool Life Sciences, 2010, pp. 23-27.

[35] R.A. Gadient, U.H. Otten, Interleukin-6 (il-6)-a molecule with both beneficial and destructive potentials, Prog. Neurobiol. 52 (1997) 379-390.

[36] A. Chalaris, C. Garbers, B. Rabe, S. Rose-John, J. Scheller, The soluble Interleukin 6 receptor: generation and role in inflammation and cancer, Eur. J. Cell Biol. 90 (2011) 484-494.

[37] J.E. Fonseca, M.J. Santos, H. Canhão, E. Choy, Interleukin-6 as a key player in systemic inflammation and joint destruction, Autoimmun. Rev. 8 (2009) $538-542$.

[38] L. Li, Z. Fei, J. Ren, R. Sun, Z. Liu, Z. Sheng, L. Wang, X. Sun, J. Yu, Z. Wang, J. Fei, Functional imaging of interleukin 1 beta expression in inflammatory process using bioluminescence imaging in transgenic mice, Biomed. Cent. Immunol. 9 (2008) 1-9.

[39] E. Voronov, Y. Carmi, R.N. Apte, The role IL-1 in tumor-mediated angiogenesis, Front. Physiol. 28 (2014) 5-114.

[40] R.V. Horssen, T.M.T. Hagen, A.M.M. Eggermont, TNF- $\alpha$ in cancer treatment: molecular insights, antitumor effects, and clinical utility, Oncologist 11 (2006) 397-408

[41] J. Jin, Y. Chang, W. Wei, Clinical application and evaluation of anti-TNF-alpha agents for the treatment of rheumatoid arthritis, Acta Pharmacol. Sin. 31 (2010) 1133-1140.

[42] T. Horiuchi, H. Mitoma, S. Harashima, H. Tsukamoto, T. Shimoda, Transmembrane TNF- $\alpha$ : structure, function and interaction with anti-TNF agents, Rheumatology 49 (2010) 1215-1228.

[43] P.A. Ruiz, D. Haller, Functional diversity of flavonoids in the inhibition of the proinflammatory NF- $\mathrm{B}$, IRF, and Akt signaling pathways in murine intestina epithelial cells, J. Nutr. 136 (2006) 664-671.

[44] J. Scheller, A. Chalaris, D. Schmidt-Arras, S. Rose-John, The pro- and antiinflammatory properties of the cytokine interleukin-6, Biochim. Biophys Acta 1813 (2011) 878-888.

[45] Q. Ke, M. Costa, Hypoxia-inducible factor-1 (HIF-1), ASPET J. 70 (2006) 1469-1480.

[46] J.E. Ziello, I.S. Jovin, Y. Huang, Hypoxia-inducible factor (HIF)-1 regulatory pathway and its potential for therapeutic intervention in malignancy and ischemia, Yale J. Biol. Med. 80 (2007) 51-60.

[47] Z. Wang, C. Dabrosin, X. Yin, M.M. Fuster, A. Arreola, W.K. Rathmell, D. Generali, G.P. Nagaraju, B. El-Rayes, D. Ribatti, Y.C. Chen, K. Honoki, H. Fujii, A.G. Georgakilas, S. Nowsheen, A. Amedei, E. Niccolai, A. Amin, S.S. Ashraf, B. Helferich, X. Yang, G. Guha, D. Bhakta, M.R. Ciriolo, K. Aquilano, S. Chen, D. Halicka, S.I. Mohammed, A.S. Azmi, A. Bilsland, W.N. Keith, L.D. Jensen, Broad targeting of angiogenesis for cancer prevention and therapy, Semin. Cancer Biol. 35 (2015) S224-S243.

[48] G. Bonizzi, M. Karin, The two NF-kB activation pathways and their role in innate and adaptive immunity, Trends Immunol. 25 (2004) 280-288.

[49] P.O. Gannon, L. Lessard, L. Stevens, V. Forest, L.R. Bégin, S. Minner, P. Tennstedt, T. Schlomm, A. Mes-Masson, F. Saad, Large-scale independent validation of the nuclear factor-kappa B p65 prognostic biomarker in prostate cancer, Eur. J. Cancer 49 (2013) 2441-2448.

[50] M. Niu, Y. Shen, X. Xu, Y. Yao, C. Fu, Z. Yan, Q. Wu, J. Cao, L. Zeng, Z. Li, X. Liu, $\mathrm{K}$. Xu, Piperlongumine selectively suppresses ABC-DLBCL through inhibition of NF-kB p65 subunit nuclear import, Biochem. Biophys. Res. Commun. 462 (2015) 326-331.

[51] M. Adli, E. Merkhofer, P. Cogswell, A.S. Baldwin, IKK $\alpha$ and IKK $\beta$ each function to regulate NF- $\mathrm{KB}$ activation in the TNF-induced/canonical pathway, PLoS One 5 (2010) e9428-e9435.

[52] H. Häcker, M. Karin, Regulation and function of IKK and IKK-related kinases, Sci. STKE 357 (2006) re13.

[53] S. Pascual-Teresa, K.L. Johnston, M.S. DuPont, K.A. ÓLeeary, P.W. Needs, L.M. Morgan, M.N. Clifford, Y. Bao, G. Williamson, Quercetin metabolites downregulate cyclooxygenase-2 transcription in human lymphocytes ex vivo but not in vivo, J. Nutr. 134 (2004) 552-557.

[54] S. Sil, T. Ghosh, Role of cox-2 mediated neuroinflammation on the neurodegeneration and cognitive impairments in colchicine induced rat model of Alzheimer's disease, J. Neuroimmunol. 291 (2016) 115-124.

[55] J. Martel-Pelletier, D. Lajeunesse, P. Reboul, J.P. Pelletier, Therapeutic role of dual inhibitors of 5-LOX and COX, selective and non-selective non-steroida anti-inflammatory drugs, Ann. Rheum. Dis. 62 (2003) 501-509.

[56] D. Lokwani, R. Azad, A. Sarkate, P. Reddanna, D. Shinde, Structure Based Library Design (SBLD) for new 1,4- dihydropyrimidine scaffold as simultaneous COX-1/COX-2 and 5-LOX inhibitors, Bioorg. Med. Chem. 23 (2015) 4533-4543.

[57] F. Aksakal, N. Shvets, A. Dimoglo, The study of dual COX-2/5-LOX inhibitors by using electronic-topological approach based on data on the ligand-receptor interactions, J. Mol. Graph. Model. 60 (2015) 79-88.
[58] I. Ben-Batalla, M. Cubas-Cordova, F. Udonta, M. Wroblewski, J.S. Waizenegger, M. Janning, S. Sawall, V. Gensch, L. Zhao, I. MartinezZubiaurre, K. Riecken, B. Fehse, K. Pantel, C. Bokemeyer, S. Loges, Cyclooxygenase-2 blockade can improve efficacy of VEGF-targeting drugs, Oncotarget 6 (2015) 6341-6358.

[59] M.C. Casimiro, M. Crosariol, E. Loro, Z. Li, R.G. Pestell, Cyclins and cell cycle control in cancer and disease, Genes Cancer 3 (2012) 649-657.

[60] J.P. Alao, The regulation of cyclin D1 degradation: roles in cancer development and the potential for therapeutic invention, Mol. Cancer 6 (2007) 24-40.

[61] S. Mazumder, E.L. DuPree, A. Almasan, A dual role of cyclin e in cell proliferation and apotosis may provide a target for cancer therapy, Curr. Cancer Drug Targets 4 (2004) 65-75.

[62] A. Salajegheh, Cyclin D1 and E1, in: A. Salajegheh (Ed.), Angiogenesis in Health, Disease and Malignancy, first ed., Springer International Publishing, Switzerland, 2016, pp. 37-42.

[63] K. Kollmann, G. Heller, C. Schneckenleithner, W. Warsch, R. Scheicher, R.G. Ott, V. Sexl, A kinase-independent function of CDK6 links the cell cycle to tumor angiogenesis, Cancer Cell 24 (2013) 167-181.

[64] T. Abbas, A. Dutta, p21 in cancer: intricate networks and multiple activities, Nat. Rev. Cancer 9 (2009) 400-414.

[65] J.H. Kim, B.J. Lee, J.H. Kim, Y.S. Yu, M.Y. Kim, K.W. Kim, Rosmarinic acid suppresses retinal neovascularization via cell cycle arrest with increase of p21 WAF1 expression, Eur. J. Pharmacol. 615 (2009) 150-154.

[66] K.T. Bieging, S.S. Mello, L.D. Attardi, Unravelling mechanisms of p53mediated tumour suppression, Nat. Rev. Cancer 14 (2014) 359-370.

[67] J. Li, J. Buchner, Structure, function and regulation of the Hsp90 machinery, Biomed. J. 36 (2013) 106-117.

[68] J. He, C. Ning, Y. Wang, T. Ma, H. Huang, Y. Ge, J. Liu, Y. Jiang, Natural plant flavonoid apigenin directly disrupts Hsp90/Cdc37 complex and inhibits pancreatic cancer cell growth and migration, J. Funct. Foods 18 (2015) 10-21.

[69] S.E. Jackson, Hsp90: structure and function, Top. Curr. Chem. 328 (2013) $155-240$.

[70] K. Staufer, O. Stoeltzing, Implication of heat shock protein 90 (HSP90) in tumor angiogenesis: a molecular target for anti-angiogenic therapy? Curr. Cancer Drug Targets 10 (2010) 890-897.

[71] P. Abeyrathna, Y. Su, The critical role of Akt in cardiovascular function, Vasc. Pharmacol. 74 (2015) 38-48.

[72] I. Hers, E.E. Vicent, J.M. Tavaré, Akt signalling in health and disease, Cell. Signal. 23 (2011) 1515-1527.

[73] L.H. Pearl, Hsp90 and Cdc37 - a chaperone cancer conspiracy, Curr. Opin. Genet. Dev. 15 (2005) 55-61.

[74] C.K. Vaughan, M. Mollapour, J.R. Smith, A. Truman, B. Hu, V.M. Good, B. Panaretou, L. Neckers, P.A. Clarke, P. Workman, P.W. Piper, C. Prodromou, L.H. Pearl, Hsp90-dependent activation of protein kinases is regulated by chaperone-targeted dephosphorylation of Cdc37, Mol. Cell 31 (2008) $886-895$.

[75] R. Datta, T. Bansal, S. Rana, K. Datta, S. Chattopadhyay, M. Chawla-Sarkar, S. Sarkar, Hsp90/Cdc37 assembly modulates TGF $\beta$ receptor-II to act as a profibrotic regulator of TGFß signaling during cardiac hypertrophy, Cell. Signal. 27 (2015) 2410-2424.

[76] R. Aikawa, I. Komuro, T. Yamazaki, Y. Zou, S. Kudoh, M. Tanaka, I. Shiojima, Y. Hiroi, Y. Yazaki, Oxidative stress activates extracellular signal-regulated kinases through Src and Ras cultured cardiac myocytes of neonatal rats, J. Clin. Invest. 100 (1997) 1813-1821.

[77] K.A. Manu, G. Kuttan, Anti-metastatic potential of punarnavine, an alkaloid from Boerhaavia diffusa Linn, Immunobiology 214 (2009) 245-255.

[78] M. Shin, T.J. Beane, A. Quillien, I. Male, L.J. Zhu, N.D. Lawson, Vegfa signals through ERK to promote angiogenesis, but not artery differentiation, Development 143 (2016) 3796-3805.

[79] X. Wang, B. Xu, J. Liu, J. Cui, Effect of $\beta$-escin sodium on endothelial cells proliferation, migration and apoptosis, Vasc. Pharmacol. 49 (2008) 158-165.

[80] K. Szabadfi, E. Pinter, D. Reglodi, R. Gabriel, Chapter one - neuropeptides, trophic factors, and other substances providing morphofunctional and metabolic protection in experimental models of diabetic retinopathy, Int Rev. Cell Mol. Biol. 311 (2014) 1-121.

[81] W. Zhang, G. Fulci, H. Wakimoto, T.A. Cheema, J.S. Buhrman, D.S. Jeyaretna, A.O.S. Rachamimov, S.D Rabkin, R.L Martuza, Combination of oncolytic herpes simplex viruses armed with angiostatin and IL-12 enhances antitumor efficacy in human glioblastoma models, NeoPlasia 15 (2013) 591-599.

[82] G.L. Klement, E. Shai, D. Varon, Chapter 24 - the role of platelets in angiogenesis, in: Platelets, $3^{\text {th }}$ Edition, Academic Press, 2013, pp. 487-502.

[83] M.S. Blumenkranz, L. Leung, D.F. Martin, P.J. Rosenfeld, M.A. Zarbin, Chapter 67 - pharmacotherapy of age-related macular degeneration, in: Retina, fifth ed., Elsevier, 2013, pp. 1213-1255.

[84] D.G. Vavvas, J.W. Miller, Chapter 26 - basic mechanisms of pathological retinal and choroidal angiogenesis, in: Retina, fifth ed ,2013, pp. 562-578.

[85] S. Seregard, C. All-Ericsson, Chapter 3 - cancer pathology and angiogenesis, Clin. Ophthalmic Oncol. (2009) 11-26.

[86] A. Albini, C. Marchisone, F.D. Grosso, R. Benelli, L. Masiello, C. Tacchetti, M. Bono, M. Ferrantini, C. Rozera, M. Truini, F. Belardelli, L. Santi, D.M. Noonan, Inhibition of angiogenesis and vascular tumor growth by interferon-producing cells, Am. J. Pathol. 156 (2000) 1381-1393. 
[87] S. Indraccolo, Interferon- $\alpha$ as angiogenesis inhibitor: learning from tumor models, J. Autoimmun. 43 (2010) 244-247.

[88] Z. Marschall, A. Scholz, T. Cramer, G. Schäfer, M. Schirner, K. Oberg, B. Wiedenmann, M. Höcker, S. Rosewicz, Effects of interferon alpha on vascular endothelial growth factor gene transcription and tumor angiogenesis, J. Natl. Cancer Inst. 19 (2003) 437-448.

[89] M.S. Filla, J.A. Faralli, J.L. Peotter, D.M. Pteres, The role of integrins in glaucoma, Exp. Eye Res. 158 (2017) 124-136.

[90] L. Lia, J. Welser-Alves, A. Flier, A. Boroujerdi, R.O. Hynes, R. Milner, An angiogenic role for the $\alpha 5 \beta 1$ integrin in promoting endothelial cell proliferation during cerebral hypoxia, Exp. Neurol. 237 (2012) 46-54.

[91] M. Millard, S. Odde, N. Neamati, Integrin targeted therapeutics, Theranostics 1 (2011) 154-188.

[92] D.N. Sauder, J. DeKoven, P. Champagne, D. Croteau, É. Dupont, Neovastat (AE941), an inhibitor of angiogenesis: randomized phase I/II clinical trial results in patients with plaque psoriasis, J. Am. Acad. Dermatol 47 (2002) 535-541.

[93] S.Y. Lee, S. Chung Neovastat, (Æ-941) inhibits the airway inflammation via VEGF and HIF-2 $\alpha$ suppression, Vasc. Pharmacol. 47 (2007) 313-318.

[94] L.M. Harkness, A.W. Ashton, J.K. Burgess, Asthma is not only an airway disease, but also a vascular disease, Pharmacol. Ther. 148 (2015) 17-33.

[95] E. Ahn, H. Jeon, E. Lim, H. Jung, E. Park, Anti-inflammatory and antiangiogenic activities of Gastrodia elata Blume, J. Ethnopharmacol. 110 (2007) 476-482.

[96] K. Dormanns, R.G. Brown, T. David, The role of nitric oxide in neurovascular coupling, J. Theor. Biol. 394 (2016) 1-17.

[97] A. El-Sehemy, L. Postovit, Y. Fu, Nitric oxide signaling in human ovarian cancer: a potential therapeutic target, Nitric Oxide 54 (2016) 30-37.

[98] S.C. Bir, Y. Xiong, C.G. Kevil, J. Luo, Emerging role of PKA/eNOS pathway in therapeutic angiogenesis for ischemic tissue diseases, Cardiovasc. Res. 95 (2012) 7-18.

[99] Y. Lee, J. Park, Y. Bae, Regulation of protein kinase CK2 catalytic activity by protein kinase C and phospholipase D2, Biochimie 121 (2016) 131-139.

[100] E. Łukowska-Chojnacka, P. Winska, M. Wielechowska, M. Poprzeczko, M. Bretner, Synthesis of novel polybrominated benzimidazole derivatives potential CK2 inhibitors with anticancer and proapoptotic activity, Bioorg. Med. Chem. 24 (2016) 735-741.

[101] M. Montenarh, Protein kinase CK2 and angiogenesis, Adv. Clin. Exp. Med. 23 (2014) 153-158.

[102] M. Zhao, J. Ma, H. Zhu, X. Zhang, Z. Du, Y. Xu, X. Yu, Apigenin inhibits proliferation and induces apoptosis in human multiple myeloma cells through targeting the trinity of CK2, Cdc37 and Hsp90, Mol. Cancer 10 (2011) 104-118.

[103] J. Moriya, N. Ferrara, Inhibition of protein kinase $C$ enhances angiogenesis induced by platelet-derived growth factor $\mathrm{C}$ in hyperglycemic endothelial cells, Cardiovasc. Diabetol. 14 (2015) 19.

[104] L. Quintieri, M. Selmy, S. Indraccolo, Metabolic effects of antiangiogenic drugs in tumors: therapeutic implications, Biochem. Pharmacol. 89 (2014) $162-170$.

[105] M.L. Barbosa, L.M. Lima, R. Tesch, C.M. Sant'Anna, F. Totzke, M.H. Kubbutat, C. Schächtele, S.A. Laufer, E.J. Barreiro, Novel 2-chloro-4-anilino-quinazoline derivatives as EGFR and VEGFR-2 dual inhibitors, Eur. J. Med. Chem. 71 (2014) 1-14.

[106] R. Oklu, T.W. Walker, S. Wicky, R. Hesketh, Angiogenesis and current antiangiogenic strategies for the treatment of cancer, J. Vasc. Interv. Radiol. 21 (2010) 1791-1805.

[107] FDA, Consulted in 03/05/2016: https://www.fda.gov/drugs/drugsafety/ postmarketdrugsafetyinformationforpatientsandproviders/ucm193900.htm.

[108] T. Shih, C. Lindley, Bevacizumab: an angiogenesis inhibitor for the treatment of solid malignancies, Clin. Ther. 28 (2006) 1779-1802.

[109] M. Potente, H. Gerhardt, P. Carmeliet, Basic and therapeutic aspects of angiogenesis, Cell 146 (2011) 873-887.

[110] National Cancer Institute consulted in 03/05/2016: http://www.cancer.gov/ about-cancer/treatment/drugs/fda-vandetanib.

[111] J.J. Hsieh, M.P. Purdue, S. Signoretti, C. Swanton, L. Albiges, M. Schmidinger, D.Y. Heng, J. Larkin, V. Ficarra, Renal cell carcinoma, Nat. Rev. Dis. Prim. 3 (2017) 17009.

[112] K.J. Gotink, H.M.V. Verheul, Anti-angiogenic tyrosine kinase inhibitors: what is their mechanism of action? Angiogenesis 13 (2010) 1-14.

[113] D. Iacopetta, A. Carocci, M.S. Sinicropi, A. Catalano, G. Lentini, J. Ceramella, R. Curcio, M.C. Caroleo, Old drug scaffold, new activity: thalidomidecorrelated compounds exert different effects on breast cancer cell growth and progression, ChemMedChem 12 (2017) 381-389.

[114] Z. Qu, C. Jiang, J. Wu, Y. Ding, Lenalidomide induces apoptosis and inhibits angiogenesis via caspase-3 and VEGF in hepatocellular carcinoma cells, Mol. Med. Rep. 14 (2016) 4781-4786.

[115] K. Lu, M. Bhat, S. Basu, Plants and their active compounds: natural molecules to target angiogenesis, Angiogenesis (2016), https://doi.org/10.1007/s10456016-9512-y.

[116] J.J. Lee, E. Chu, Sequencing of antiangiogenic agents in the treatment of metastatic colorectal cancer, Clin. Colorectal Cancer 13 (2014) 135-144.

[117] N. Bhojani, C. Jaldres, J. Patard, P. Perrotte, N. Suardi, G. Hutterer, F. Patenaude, S. Oudard, P.I. Karakiewicz, Toxicities associated with the administration of sorafenib, sunitinib, and temsirolimus and their management in patients with metastatic renal cell carcinoma, Eur. Urol. 53 (2008) 917-930.
[118] S. Nobili, D. Lippi, E. Witort, M. Donnini, L. Bausi, E. Mini, S. Capaccioli, Natural compounds for cancer treatment and prevention, Pharmacol. Res. 59 (2009) 365-378.

[119] S.M. Sagar, D. Yance, R.K. Wong, Natural health products that inhibit angiogenesis: a potential source for investigational new agents to treat cancer - Part 1, Curr. Oncol. 13 (2006) 14-26.

[120] E. Seo, V. Kuete, O. Kadioglu, B. Krusche, S. Schröder, H.J. Greten, J. Arend I. Lee, T. Efferth, Antiangiogenic activity and pharmacogenomics of medicinal plants from traditional Korean medicine, J. Evid. Based Complement. Altern. Med. 2013 (2013) 1-13.

[121] X.X. Zhu, L. Yang, Y.J. Li, D. Zhang, Y. Chen, P. Kostecká, E. Kmoníèková Z. Zídek, Effects of sesquiterpene, flavonoid and coumarin types of compounds from Artemisia annua L. on production of mediators of angiogenesis, Pharmacol. Rep. 65 (2013) 410-420.

[122] R.M. Ghalib, R. Hashim, O. Sulaiman, S.H. Mehdi, A. Valkonen, K. Rissanen, S.R. Trifunović, M.B.K. Ahamed, A.M.S.A. Majid, F. Kawamura, A novel caryophyllene type sesquiterpene lactone from Asparagus falcatus (Linn.) structure elucidation and anti-angiogenic activity on HUVECs, Eur. J. Med. Chem. 47 (2012) 601-607.

[123] R. Guimarães, R.C. Calhelha, H.J. Froufe, R.M. Abreu, A.M. Carvalho, M.J. Queiroz, I.C.F.R. Ferreira, Wild Roman chamomile extracts and phenolic compounds: enzymatic assays and molecular modelling studies with VEGFR2 tyrosine kinase, Food Funct. 7 (2016) 79-83.

[124] W. Huang, J. Wang, Y. Liang, W. Ge, G. Wang, Y. Li, H.Y. Chung, Potent antiangiogenic component in Croton crassifolius and its mechanism of action, J. Ethnopharmacol. 175 (2015) 185-191.

[125] O.S.A. Al-Salahi, C. Kit-Lam, A.M.S.A. Majid, F.S.R. Al-Suede, S.A.M. Saghir, W.Z. Abdullah, M.B.K. Ahamed, N.M. Yusoff, Anti-angiogenic quassinoid-rich fraction from Eurycoma longifolia modulates endothelial cell function, Microvasc. Res. 90 (2013) 30-39.

[126] R.B. Bostancioğlu, M. Kürkçüoğlu, K.H.C. Bașer, A.T. Koparal, Assessment of anti-angiogenic and anti-tumoral potentials of Origanum onites L. essential oil, Food Chem. Toxicol. 50 (2012) 2002-2008.

[127] N. Kadria, B. Khettal, A. Adjebli, T. Cresteil, R. Yahiaoui-Zaidib, V. BarraganMonteroa, J. Montero, Antiangiogenic activity of neutral lipids, glycolipids, and phospholipids fractions of Pinus halepensis Mill. seeds, Ind. Crops Prod. 54 (2014) 6-12.

[128] V.T. Nguyen, N.T. Tung, T.D. Cuong, T.M. Hung, J.A. Kim, M.H. Woo, J.S. Choi, J. Lee, B.S. Min, Cytotoxic and anti-angiogenic effects of lanostane triterpenoids from Ganoderma lucidum, Phytochem. Lett. 12 (2015) 69-74.

[129] Y.S. Lee, Y.H. Kim, E.K. Shin, D.H. Kim, S.S. Lim, J.Y. Lee, J.K. Kim, Antiangiogenic activity of methanol extract of Phellinus linteus and its fractions, J. Ethnopharmacol. 131 (2010) 56-62.

[130] S. Lin, L.T. Ching, J. Chen, P.C.K. Cheung, Antioxidant and anti-angiogenic effects of mushroom phenolics-rich fractions, J. Funct. Foods 17 (2015) $802-815$.

[131] S.U. Mertens-Talcott, S.T. Talcott, S.S. Percival, Low concentrations of quercetin and ellagic acid synergistically influence proliferation, cytotoxicity and apoptosis in molt-4 human leukemia cells, Nutr. Cancer 133 (2003) 2669-2674.

[132] S.U. Mertens-Talcott, S.S. Percival, Ellagic acid and quercetin interact synergistically with resveratrol in the induction of apoptosis and cause transient cell cycle arrest in human leukemia cells, Cancer Lett. 218 (2005) 141-151.

[133] D. Bagchi, C.K. Sen, M. Bagchi, M. Atalay, Anti-angiogenic, antioxidant, and anti-carcinogenic properties of a novel anthocyanin-rich berry extract formula, Biochemistry 69 (2004) 75-80.

[134] J. Zhou, L. Yu, G.L. Blackburn, Soy phytochemicals and tea bioactive components synergistically inhibit androgen-sensitive human prostate tumors in mice, J. Nutr. 133 (2003) 516-521.

[135] J. Zhou, L. Yu, Z. Mai, G.L. Blackburn, Combined inhibition of estrogendependent humen breast carcinoma by soy and tea bioactive components in mice, Inter. J. Cancer 108 (2004) 8-14.

[136] I. Paur, T.R. Balstad, M. Kolberg, M.K. Pedersen, L.M. Austenaa, D.R. Jacobs R. Blomhoff, Extract of oregano, coffee, thyme, clove, and walnuts inhibits nf$\kappa \mathrm{b}$ in monocytes and in transgenic reporter mice, Cancer Prev. Res. 3 (2010) 653-663.

[137] J.H. Kim, B.J. Lee, J.H. Kim, Y.S. Yu, K.W. Kim, Anti-angiogenic effect of caffeic acid on retinal neovascularization, Vasc. Pharmacol. 51 (2009) 262-267.

[138] L. Liu, Y. Jing, L.L. Jiang, X.E. Jiang, Y. Jiang, Y. Rojanasakul, B. Jiang, Acacetin inhibits VEGF expression, tumor angiogenesis and growth through AKT/HIF$1 \alpha$ pathway, Biochem. Biophys. Res. Commun. 413 (2011) 299-305.

[139] K. Banerjee, M. Mandal, Oxidative stress triggered by naturally occurring flavone apigenin results in senescence and chemotherapeutic effect in human colorectal cancer cells, Redox Biol. 5 (2015) 153-162.

[140] D. Wu, P. Yu, J. Li, P. Jiang, J. Sun, H. Wang, L. Zhang, M. Wen, P. Bie, Apigenin potentiates the growth inhibitory effects by IKK- $\beta$-mediated NF- $\mathrm{B}$ B activation in pancreatic cancer cells, Toxicol. Lett. 224 (2014) 157-164.

[141] S.K. Rodriguez, W. Guo, L. Liu, M.A. Band, E.K. Paulson, M. Meydani, Green tea catechin, epigallocatechin-3-gallate, inhibits vascular endothelial growth factor angiogenic signaling by disrupting the formation of a receptor complex, Inter. J. Cancer 118 (2006) 1635-1644.

[142] B. Wang, Y. Zou, H. Li, H. Yan, J. Pan, Z. Yuan, Genistein inhibited retinal neovascularization and expression of vascular endothelial growth factor and hypoxia inducible factor $1 \alpha$ in a mouse model of oxygen-induced retinopathy, J. Ocul. Pharmacol. Ther. 21 (2005) 107-113. 
[143] V.S. Rathinasamy, N. Paneerselvan, M. Ragunathan, Effect of genistein on regenerative angiogenesis using zebrafish as model organism, Biomed. Prev. Nutr. 4 (2014) 469-474.

[144] L. Pu, H. Chen, M. Cao, X. Zhang, Q. Gao, C. Yuan, C. Wang, The antiangiogenic activity of Kushecarpin D, a novel flavonoid isolated from Sophora flavescens Ait, Life Sci. 93 (2013) 791-797.

[145] J.L. Johnson, E.G. Mejia, Interactions between dietary flavonoids apigenin or luteolin and chemotherapeutic drugs to potentiate anti-proliferative effect on human pancreatic cancer cells, in vitro, Food Chem. Toxicol. 60 (2013) 83-91.

[146] D. Zhao, C. Qin, X. Fan, Y. Li, B. Gu, Inhibitory effects of quercetin on angiogenesis in larval zebrafish and human umbilical vein endothelial cells, Eur. J. Pharmacol. 723 (2014) 360-367.

[147] C. Fortes, J.A. García-Vilas, A.R. Quesada, M.A. Medina, Evaluation of the antiangiogenic potential of hydroxytyrosol and tyrosol, two bio-active phenolic compounds of extra virgin olive oil, in endothelial cell cultures, Food Chem. 134 (2012) 134-140.

[148] E. Bråkenhielm, R. Cao, Y. Cao, Suppression of angiogenesis, tumor growth,and wound healing by resveratrol, a natural compound in red wine and grapes, FASEB J. 15 (2001) 1798-1800.

[149] K. Igura, T. Ohta, Y. Kuroda, K. Kaji, Resveratrol and quercetin inhibit angiogenesis in vitro, Cancer Lett. 171 (2001) 11-16.

[150] H. Zhang, S. He, C. Spee, K. Ishikawa, D.R. Hinton, SIRT1 mediated inhibition of VEGF/VEGFR2 signaling by resveratrol and its relevance to choroidal neovascularization, Cytokine 76 (2015) 549-552.

[151] K.B. Cullberg, J. Olholm, S.K. Paulsen, C.B. Foldager, M. Lind, B. Richelsen, S.B. Pedersen, Resveratrol has inhibitory effects on the hypoxia-induced inflammation and angiogenesis in human adipose tissue in vitro, Eur. J. Pharm. Sci. 49 (2013) 251-257.

[152] F.C.M. Lopes, A. Rocha, A. Picarro, L.O. Regasini, D.H.S. Silva, V.S. Bolzani, I. Azevedo, I.Z. Carlos, R. Soares, Anti-angiogenic effects of pterogunidine alkaloid isolated from Alchornea glandulosa, BMC Compl. Altern. Med. 9 (2009) 1-11.

[153] S. Saraswati, A.A. Alhaider, S.S. Agrawal, Punarnavine, an alkaloid from Boerhaavia diffusa exhibits anti-angiogenic activity via downregulation of VEGF in vitro and in vivo, Chem. Biol. Interact. 206 (2013) 204-213.

[154] J. Zhao, W. Lin, Q. Zhuang, X. Zhong, Z. Cao, Z. Hong, J. Peng, Total alkaloids of Rubus alceifolius poir shows anti-angiogenic activity in vivo and in vitro, Integr. Cancer Ther. 13 (2014) 520-528.

[155] P. Ganesan, K. Matsubara, T. Sugawara, T. Hirata, Marine algal carotenoids inhibit angiogenesis by down-regulating FGF-2-mediated intracellular signals in vascular endothelial cells, Mol. Cell. Biochem. 380 (2013) 1-9.

[156] S. Kuhnen, P.M.M. Lemos, L.H. Campestrim, J.B. Ogliari, P.F. Dias, M. Maraschin, Antiangiogenic properties of carotenoids: a potential role of maize as functional food, J. Funct. Foods 1 (2009) 284-290.

[157] Y. Huang, Y. Zhou, Y. Fan, D. Zhou, Celastrol inhibits the growth of human glioma xenografts in nude mice through suppressing VEGFR expression, Cancer Lett. 264 (2008) 101-106.

[158] G. Sethi, K.S. Ahn, M.K. Pandey, B.B. Aggarwal, Celastrol, a novel triterpene, potentiates TNF-induced apoptosis and suppresses invasion of tumor cells by inhibiting NF-kB-regulated gene products and TAK1-mediated NF-kB activation, Blood 109 (2007) 2727-2735.

[159] H. Matsuda, Y. Li, T. Murakami, K. Ninomiya, J. Yamahara, M. Yoshikawa, Effects of escins Ia, Ib, IIa, and IIb from horse chestnut, the seeds of Aesculus hippocastanum L., on acute inflammation in animals, Biol. Pharm. Bull. 20 (1997) 1092-1095.

[160] Z. Zhong, P. Hoi, G. Wu, Z. Xu, W. Tan, X. Chen, L. Cui, T. Wu, Y. Wang, Antiangiogenic effect of furanodiene on HUVECs in vitro and on zebrafish in vivo, J. Ethnopharmacol. 141 (2012) 721-727.

[161] J.Y. Chan, J.C. Koon, X. Liu, M. Detmar, B. Yu, S. Kong, K. Fung, Polyphyllin D, a steroidal saponin from Paris polyphylla, inhibits endothelial cell function in vitro and angiogenesis in zebrafish embryos in vivo, J. Ethnopharmacol. 137 (2011) 64-69.

[162] K.S. Prasanna, P. Shilpa, B.P. Salimath, Withaferin A suppresses the expression of vascular endothelial growth factor in Ehrlich ascites tumor cells via Sp1 transcription factor, Curr. Trends Biotechnol. Pharm. 3 (2009) 138-148.

[163] D.H. Lee, I. Lim, E. Sung J. Kim, I. Song Y. Park, T. Lee, Withaferin A inhibits matrix metalloproteinase-9 activity by suppressing the Akt signaling pathway, Oncol. Rep. 30 (2013) 933-938.

[164] S. Saha, M.K. Islam, J.A. Shilpil, S. Hasan, Inhibition of VEGF: a novel mechanism to control angiogenesis by Withania somnifera's key metabolite Withaferin A, Silico Pharmacol. 1 (2013) 11-20.

[165] R. Mohan, H.J. Hammers, P. Bargagna-Mohan, H.X. Zhan, C.J. Herbstritt, A. Ruiz, L. Zhang A.D. Hanson, B.P. Corner, J. Rougas, V.S. Pribluda, Withaferin A is a potent inhibitor of angiogenesis, Angiogenesis 7 (2004) 115-122.

[166] R. Gao, N. Shan, J. Lee, S.P. Katiyar, L. Li, E. Oh, D. Sundar, C. Yun, R. Wadhwa, S.C. Kaul, Withanone-rich combination of Ashwagandha withanolides restricts metastasis and angiogenesis through hnRNP-K, Mol. Cancer Ther. 13 (2014) 2930-2940.

[167] S. Chatterjee, B. Bhattacharjee, Use of natural molecules as anti-angiogenic inhibitors for vascular endothelial growth factor receptor, Bioinformation 8 (2012) 1249-1254

[168] L. Reddy, B. Odhav, K.D. Bhoola, Natural products for cancer prevention: a global perspective, Pharmacol. Ther. 99 (2003) 1-13.

[169] D. Peer, J.M. Karp, S. Hong, O.C. Farokhzad, R. Margalit, R. Langer, Nanocarriers as an emerging platform for cancer therapy, Nat. Nanotechnol. 2 (2007) 751-760.

[170] L. Wang, H. Li, S. Wang, R. Liu, Z. Wu, C. Wang, Y. Wang, M. Chen, Enhancing the antitumor activity of berberine hydrochloride by solid lipid nanoparticle encapsulation, AAPS J. 15 (2014) 834-844.

[171] I. Siddiqui, V.M. Adhami, D.J. Bharali, B.B. Hafeez, M. Assim, S.I. Khwaja, N. Ahmad, H. Cui, S.A. Mousa, H. Mukhtar, Introducing nanochemoprevention as a novel approach for cancer control: proof of principle with green tea polyphenol epigallocatechin-3-gallate, Cancer Res. 69 (2009) $1712-1716$.

[172] M. Gou, K. Men, H. Shi, M. Xiang, J. Zhang, J. Song, J. Long, Y. Wan, F. Luo, X. Zhao, Z. Qian, Curcumin-loaded biodegradable polymeric micelles for colon cancer therapy in vitro and in vivo, Nanoscale 3 (2011) 1558-1567.

[173] D. Huang, H. Lan, F. Liu, S. Wang, X. Chen, K. Jin, X. Mou, Anti-angiogenesis or pro-angiogenesis for cancer treatment: focus on drug distribution, Int. J. Clin. Exp. Med. 8 (2015) 8369-8376.

[174] N.M. Tannir, G. Schwab, V. Grünwald, Cabozantinib: an active novel multikinase inhibitor in renal cell carcinoma, Curr. Oncol. Rep. 19 (2017) 14.

[175] S. Sleijfer, I. Ray-Coquard, Z. Papai, A. Le-Cesne, M. Scurr, P. Schöffski, F. Collin, L. Pandite, S. Marreaud, A. De-Brauwer, M. van-Glabbeke, J. Verweij, J.Y. Blay, Pazopanib, a multikinase angiogenesis inhibitor, in patients with relapsed or refractory advanced soft tissue sarcoma: a phase II study from the European organisation for research and treatment of cancer-soft tissue and bone sarcoma group, Clin. Oncol. 27 (2009) 3126-3132.

[176] Y. Krupitskaya, H.A. Wakelee, Ramucirumab, a fully human mAb to the transmembrane signaling tyrosine kinase VEGFR-2 for the potential treatment of cancer, Curr. Opin. Investig. Drugs 10 (2009) 597-605.

[177] L. Abou-Elkacem, S. Arns, G. Brix, F. Gremse, D. Zopf, F. Kiessling, W. Lederle, Regorafenib inhibits growth, angiogenesis, and metastasis in a highly aggressive, orthotopic colon cancer model, Mol. Cancer Ther. 12 (2013) $1322-1331$.

[178] R.J. D'Amato, M.S. Loughnan, E. Flynn, J. Folkman, Thalidomide is an inhibitor of angiogenesis, Proc. Natl. Acad. Sci. 91 (1994) 4082-4085.

[179] L. Valerio, L. Pieruzzi, C. Giani, L. Agate, V. Bottici, L. Lorusso, V. Cappagli, L. Puleo, A. Matrone, D. Viola, C. Romei, R. Ciampi, E. Molinaro, R. Elisei, Targeted therapy in thyroid cancer: state of the art, Clin. Oncol. 6555 (2017) 30110-30113. 